\title{
放射性廃棄物の地下空洞型処分施設に用いる 区画内充てん材の施工品質の評価
}

\author{
武地 真一 1 ・横関 康祐 2 新保 弘 3 ・ \\ 寺田 賢二 $4 \cdot$ 秋山 吉弘 4 - 矢田 勤 4 - 辻 幸和 5 \\ 1正会員 鹿島建設株式会社 東北支店（干980-0802 宮城県仙台市青葉区二日町1-27） \\ E-mail: takechishinichi@kajima.com \\ 2正会員＼cjkstart鹿島建設株式会社土木管理本部（干107-8348 東京都港区赤坂6-5-11） \\ E-mail: yokozeki@kajima.com \\ 3正会員 鹿島建設株式会社 土木設計本部（†107-8502 東京都港区赤坂6-5-30 KIビル） \\ E-mail: shimbo@kajima.com
}

4正会員 公益財団法人原子力環境整備促進・資金管理センター（†104-0052 東京都中央区月島1-15-7）

E-mail: terada@rwmc.or.jp

5フェロー会員＼cjkstart前橋工科大学（†371-0816 群馬県前橋市上佐鳥町460）

E-mail: tsuji@maebashi-it.ac.jp

\begin{abstract}
地下空洞型放射性廃棄物処分施設に用いる区画内充てん材は，崩壊熱により高温環境となる可能性があ る廃棄体の周囲に直接打ち込まれることから，その充てん性や硬化性状への悪影響が懸念される。また， 区画内充てん材は放射線環境下での施工となるため, 遠隔操作による無人化施工で所定の施工品質を確保 する必要があるなど，施設特有の課題もある.

本論文では，高温環境を模擬した充てん性試験により区画内充てん材の配合を選定し，高温養生試験を 行ってその硬化性状への温度の影響を明らかにした。さらに，実規模試験により，ポンプ圧送と移動式バ ケット方式による無人化施工を実現可能とした.
\end{abstract}

Key Words : radioactive wastes, filler, disposal facility, temperature influence, unmanned construction

1. はじめに

放射性廃棄物の地下空洞型処分施設は，原子力発電所 の廃棄物の余裕深度処分として，具体的な検討が行われ ている11. 余裕深度処分とは，地下利用に十分余裕をも った深度（表層から50～100m）に廃棄物を処分するも のである. これまで，余裕深度処分施設の設計と品質管 理の考え方は，土木学会2)等により検討されてきた. 図1に余裕深度処分施設に適用が検討されている施設構成 を示す．施設は要求性能に応じた様々な部材で構成され

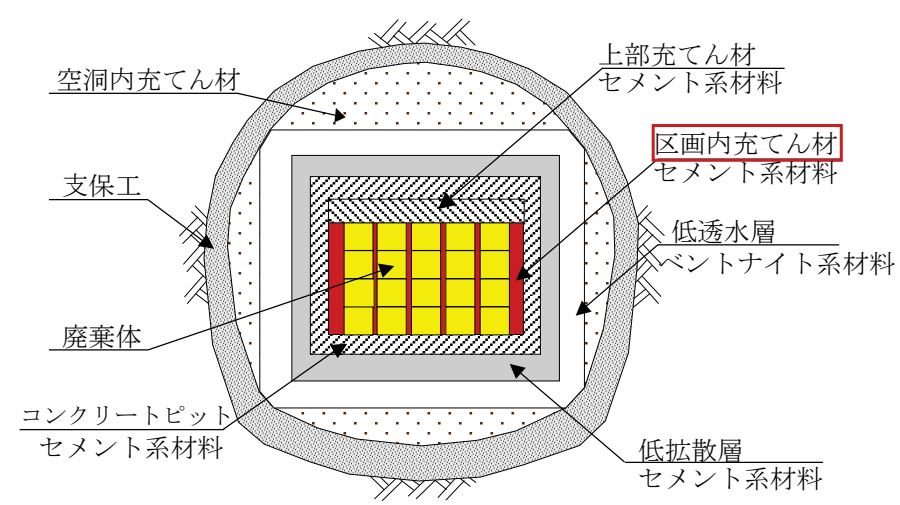

図-1 地下空洞型処分の施設構成 (土木学会2)より一部改変)

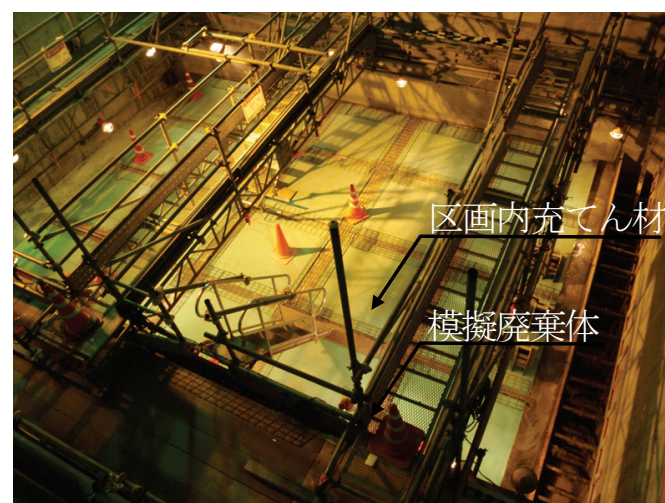

写真-1 区画内充てん材の打込み箇所全景 
ており，廃棄体の周囲には「区画内充てん材」が配置さ れる計画である. 土木学会2では，「区画内充てん材」 は一般部（廃棄体間または廃棄体とコンクリートピット 間）と上部（廃棄体上部）を分割施工寸る場合を想定し ている，本論文では一般部のみを対象としており，以下 これを「区画内充てん材」として記述する.

写真-1は，実規模試験により模擬廃棄体間に充てんし た区画内充てん材の全景である. 区画内充てん材の施設 特有の施工条件に関する課題としては，廃棄体の発熱に よる環境温度の上昇が及ぼす影響, 荷卸し場所からの放 射線管理区域の場内運搬方法，廃棄体間の間隙寸法に対 する充てん性があった。

本稿では，これら課題に対して室内および地下空洞を 利用した実規模試験により検討した結果を報告する.

\section{2. 区画内充てん材の概要と課題}

余裕深度処分施設の部材毎の要求機能は，土木学会2) によりまとめられている. 区画内充てん材の要求機能は, 施設の建設操業時の遮へい性と埋戻し後の移行抑制とし ての放射性核種の収着性である（表-1）。このうち，遮 へい性は部材厚さと材料の単位容積質量, 圧縮強度で決

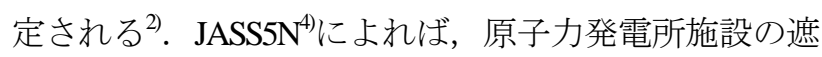
へい性を必要とするコンクリートにおいては，乾燥単位 容積質量が要求性能の主要なファクターとなる.

区画内充て几材特有の施工条件として，廃棄体発熱に よる環境温度, 荷卸し場所からの放射線管理区域におけ る場内運搬，放射線管理下での施工が挙げられる，その ため, 区画内充てん材には, 施工上要求される機能とし て施設特有の施工条件を考慮した流動性や自己充てん性, 材料分離抵抗性などの施工性を考える必要がある。それ らの課題について以下に示寸.

\section{(1) 環境温度の影響}

地下空洞型放射性廃棄物処分施設では，発熱性の廃棄 体を空洞内に高い密度で集積して定置するため, 廃棄体 の表面温度が上昇することが考えられる. 参考として, 新保ら ${ }^{5}$ の検討では, 空気温度 $+10^{\circ} \mathrm{C}$ 程度の上昇が想定さ れている. 廃棄体の間隙をセメント系充てん材で充てん 寸る際, 高温の廃棄体に触れることにより流動性が低下
すること, 養生温度が変わることで硬化体に悪影響を与 えることが懸念される. したがって, 高温環境でも流動 性が保持される材料が求められるとともに, 硬化体に与 える諸品質への影響を確認する必要がある.

\section{(2) 放射線管理区域での場内運搬方法}

区画内充てん材は，図-2に示寸ように，アジテータ車 からの荷卸し場所から施工場所までの放射線管理下にお いて，150〜250m程度の比較的長い場内運搬が必要とな る. 場内運搬方法は，配管敷設によるポンプ圧送あるい は移動式バケットによる運搬が考えられる．ポンプ圧送 の場合，圧送機に負荷される圧力や材料分離抵抗性を含 めた圧送性が必要である。また，移動式バケットによる 方法では, 遠隔操作を考慮した施工方法の確立が求めら れる.

\section{（3）自己充てん性}

廃棄体の間隙幅は，150mmと260mmの格子状が想定さ れている. 区画内充てん材は，廃棄体間の間隙および廃 棄体とコンクリートピットといった狭险な空間において

表-1 区画内充てん材の要求機能2)

\begin{tabular}{|c|c|c|c|c|}
\hline \multicolumn{2}{|c|}{ 要求機能 } & 段 & 機能の内容 & $\begin{array}{l}\text { 機能 } \\
\text { の } \\
\text { 要否 }\end{array}$ \\
\hline \multirow{8}{*}{$\begin{array}{l}\text { 基 } \\
\text { 案 } \\
\text { 荃 } \\
\text { 機 } \\
\text { 能 }\end{array}$} & $\begin{array}{l}\text { 閉じ } \\
\text { 込め }\end{array}$ & \multirow{2}{*}{\begin{tabular}{|l} 
建 \\
設 \\
湢 \\
業
\end{tabular}} & $\begin{array}{l}\text { 放射線物質の埋設施設外の環境へ } \\
\text { の有意な漏洩を防止すること }\end{array}$ & - \\
\hline & $\begin{array}{l}\text { 遮へ } \\
W\end{array}$ & & $\begin{array}{l}\text { 廃棄体を線源とする放射線に対し } \\
\text { て，十分な遮へいを有する環境を } \\
\text { 保つこと }\end{array}$ & 0 \\
\hline & \multirow{4}{*}{$\begin{array}{l}\text { 移行 } \\
\text { 抑制 }\end{array}$} & \multirow{6}{*}{ 埋 } & $\begin{array}{l}\text { 放射性榜種の拡散による移動を抑 } \\
\text { 制すること }\end{array}$ & - \\
\hline & & & 放射性核種を収着すること & 0 \\
\hline & & & $\begin{array}{l}\text { 低透水性により, 処分施設を通過 } \\
\text { する地下水流量の抑制を行うこと }\end{array}$ & - \\
\hline & & & $\begin{array}{l}\text { 連続した地下水移行経路を形成し } \\
\text { ないこと }\end{array}$ & - \\
\hline & \multirow{2}{*}{ 離隔 } & & 離隔距離を確保すること & - \\
\hline & & & 容易な侵入を防止すること & - \\
\hline \multirow{2}{*}{\multicolumn{2}{|c|}{$\begin{array}{l}\text { 操業上の } \\
\text { 機能 }\end{array}$}} & \multirow{2}{*}{\begin{tabular}{|l} 
建 \\
設 \\
湢 \\
業
\end{tabular}} & $\begin{array}{l}\text { 確実な建設, 操業が行われる空 } \\
\text { 間, 力学安定性が確保されること }\end{array}$ & - \\
\hline & & & 坑道の形状を維持すること & - \\
\hline
\end{tabular}

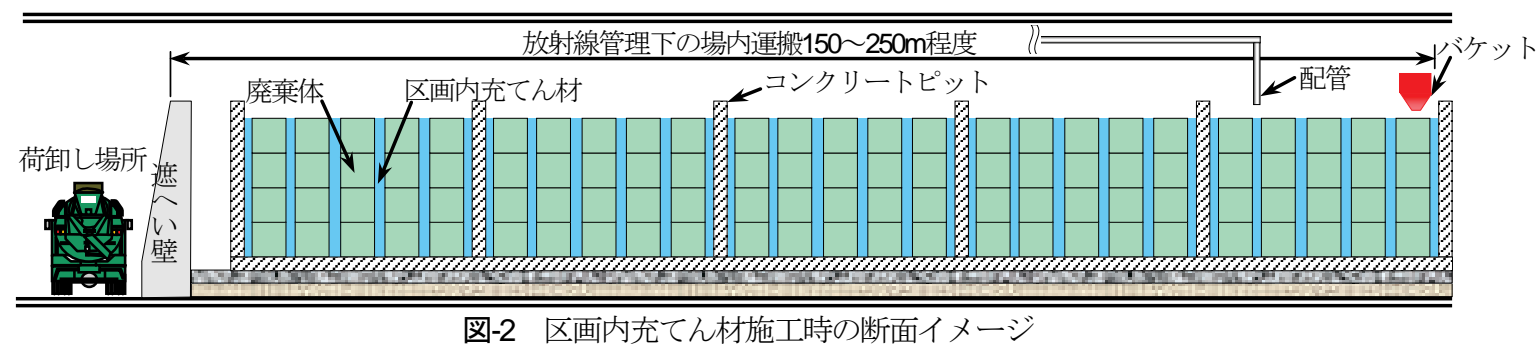


表-2 本試験の検討項目と実施内容

\begin{tabular}{|c|c|c|}
\hline \multicolumn{2}{|r|}{ 検討項目 } & 実施内容 \\
\hline (1) & $\begin{array}{l}\text { 廃棄体の発熱を考慮 } \\
\text { した配合選定 }\end{array}$ & $\begin{array}{l}\text { 設定した温度環境での流動 } \\
\text { 性確認試験を室内にて央施 }\end{array}$ \\
\hline (2) & $\begin{array}{l}\text { 高温環境で養生され } \\
\text { た硬化体の物性 }\end{array}$ & $\begin{array}{l}\text { 養生温度を変化させ，圧縮 } \\
\text { 強度，長さ変化等を室内試 } \\
\text { 験で確認 }\end{array}$ \\
\hline (3) & 長距離圧送性 & $\begin{array}{l}\text { 地上ヤードで配管を敷設 } \\
\text { し，圧送試験を実施 }\end{array}$ \\
\hline \multirow{2}{*}{ (4) } & $\begin{array}{l}\text { 場内運搬方法をポン } \\
\text { プ圧送とした自己充 } \\
\text { てん性 }\end{array}$ & $\begin{array}{l}\text { ポンプ車を用いて空洞内で } \\
\text { 実規模の施工試験を実施 }\end{array}$ \\
\hline & $\begin{array}{l}\text { 場内運搬方法に移動 } \\
\text { 式バケットを想定し } \\
\text { た自己充てん性 }\end{array}$ & $\begin{array}{l}\text { 移動式バケットを想定した } \\
\text { 仮設を構築し，空洞内で実 } \\
\text { 規模の施工試験を実施 }\end{array}$ \\
\hline (5) & $\begin{array}{l}\text { 打込み時の側圧が他 } \\
\text { 部材へ与える影響 }\end{array}$ & $\begin{array}{l}\text { 空洞内で } 6 \mathrm{~m} \text { の高さを一度 } \\
\text { に打込み, 側圧および隣接 } \\
\text { 部材の挙動を計測 }\end{array}$ \\
\hline
\end{tabular}

隙間無く充てんされることが要求される. 区画内充てん 材の打込みは放射線管理下であるため，材料には直接的 な作業を極力必要としない自己充てん性が要求される.

\section{（4）打込み時の他部材への影響}

区画内充てん材をピット内において一括で打ち込みし た場合，打込み時の側圧が隣接する部材であるピットの 壁部材にひび割れの発生等の影響を与える可能性がある.

\section{3. 検討項目および実施内容}

前述のように，区画内充てん材には地下施設特有の施 工条件（長距離の場内運搬）や廃棄体の発熱，放射線管 理下の施工に課題があった。 これらの課題に対して, 本 研究での検討項目と実施内容を表-2に整理し, 以下に検 討した内容について個別に述べる.

\section{4. 廃棄体の発熱を考慮した配合選定}

区画内充てん材は，自己充てん性が求められる材料で ある.ここで，余裕深度処分施設では流動性や充てん性 に優れた高流動モルタルを用いた低拡散層の研究が先行 しているす, カ.

本研究では，この低拡散層の配合（表-3）を基本とし て，充てん性の向上と高温環境でも充てん性が損なわれ ない配合を検討した．また，硬化体の諸性能のうち圧縮 強度は，一般構造物と同程度の $30 \mathrm{~N} / \mathrm{mm}^{2}$ を目安とするこ ととした．使用材料を表-4に，試験方法を表-5に示寸。 室内試験では，容量50リットルの水平二軸ミキサで練混 ぜた。

練混ぜ時間と投入材料は次のとおりである.
表-3 低拡散層の配合 ${ }^{3)}$

\begin{tabular}{|c|c|c|c|c|c|c|c|c|}
\hline W/B & LP/B & \multicolumn{5}{|c|}{ 単位量 $\left(\mathrm{kg} / \mathrm{m}^{3}\right)$} & \multirow{2}{*}{$\begin{array}{c}\text { SP1 } \\
\text { P×\% }\end{array}$} \\
\hline (\% & $(\%)$ & W & LPC & FA & LEX & LP & S & P×\% \\
\hline 450 & 230 & 338 & 153 & 20 & 307 & 1197 & 0.68 \\
\hline
\end{tabular}

スランプフロー $65 \pm 5 \mathrm{~cm}$, 空気量 $2.5 \pm 1.5 \%$

$\mathrm{LEX}=$ 膨張材,結合材 $\mathrm{B}=\mathrm{LPC}+\mathrm{FA}+\mathrm{LEX}$,粉体量 $\mathrm{P}=\mathrm{B}+\mathrm{LP}$

表-4 使用材料

\begin{tabular}{|c|c|c|}
\hline 材料 & 記号 & 概要 \\
\hline セメント & LPC & \begin{tabular}{|l} 
低熱ポルトランドセメント \\
密度 $=3.22 \mathrm{~g} / \mathrm{cm}^{3}, \quad$ 比表面積 $=3,530 \mathrm{~cm}^{2} / \mathrm{g}$ \\
\end{tabular} \\
\hline 細骨材 & S & $\begin{array}{l}\text { 石灰石砕砂（八戸松館産） } \\
\text { 密度 }=2.66 \mathrm{~g} / \mathrm{cm}^{3}, \quad \mathrm{FM}=2.79, \quad \mathrm{CaCO}_{3}=98 \% \\
\end{array}$ \\
\hline $\begin{array}{l}\text { 石灰石 } \\
\text { 微粉末 }\end{array}$ & LP & $\begin{array}{l}\text { 宮城産, 密度 }=2.70 \mathrm{~g} / \mathrm{cm}^{3}, \\
\text { 比表面積 }=5,050 \mathrm{~cm}^{2} / \mathrm{g}, \quad \mathrm{CaCO}_{3}=97 \% \\
\end{array}$ \\
\hline $\begin{array}{l}\text { フライ } \\
\text { アッシュ } \\
\end{array}$ & FA & $\begin{array}{l}\text { フライアッシュ II種, 密度 }=2.18 \mathrm{~g} / \mathrm{cm}^{3} \\
\text { 比表面積 }=3,790 \mathrm{~cm}^{2} / \mathrm{g}\end{array}$ \\
\hline \multirow{6}{*}{ 混和剤 } & SP1 & \begin{tabular}{|l} 
高性能AE減水剤 : \\
カルボキシル基含有ポリエーテル系化合物
\end{tabular} \\
\hline & SP2 & \begin{tabular}{|l} 
高性能AE減水剤： \\
ポリカルボン酸エーテル系化合物
\end{tabular} \\
\hline & SP3 & $\begin{array}{l}\text { 高性能AE減水刘：ポリカルボン酸エーテ } \\
\text { ル系化合物と配合ポリマーの複合体 }\end{array}$ \\
\hline & SP4 & $\begin{array}{l}\text { 高性能AE減水剤 : } \\
\text { カルボキシル基含有ポリエーテル系化合物 }\end{array}$ \\
\hline & Ad & $\begin{array}{l}\text { 減水剂 遅延型 : 変性リグニンスルホン酸 } \\
\text { 化合物とオキシカルボン酸化合物の複合体 } \\
\end{array}$ \\
\hline & AS & $\begin{array}{l}\text { 空気量調整剂： } \\
\text { ポリアルギリンー誘導体 }\end{array}$ \\
\hline
\end{tabular}

表-5 試験方法

\begin{tabular}{|l|l|}
\hline \multicolumn{1}{|c|}{ 項目 } & \multicolumn{1}{c|}{ 方法 } \\
\hline スランプフロー & JISA1150 \\
\hline 漏斗流下時間 & $\begin{array}{l}\text { JSCE-F512モルタル用 V漏斗 } \\
\text { (排出口 30×30mm) }\end{array}$ \\
\hline 流動性確認試験 & $\begin{array}{l}\text { 充てん対象間隙を模擬して製作し } \\
\text { た試験装置による }\end{array}$ \\
\hline 凝結試験 & JISA1147 \\
\hline
\end{tabular}

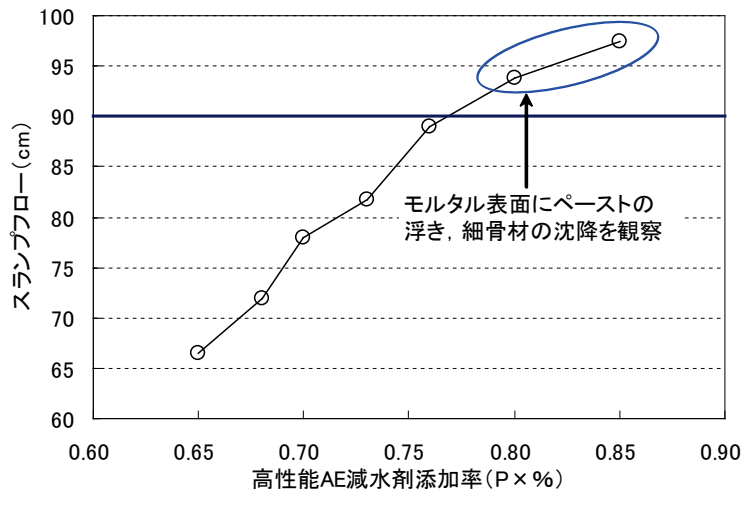

図-3＼cjkstart混和剤添加率とスランプフロー

$<$ 空練り 10 秒練混ぜ $\rightarrow$ 水 $(+$ 混和剤) 投入後 180 秒練混ぜ $\rightarrow$

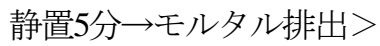




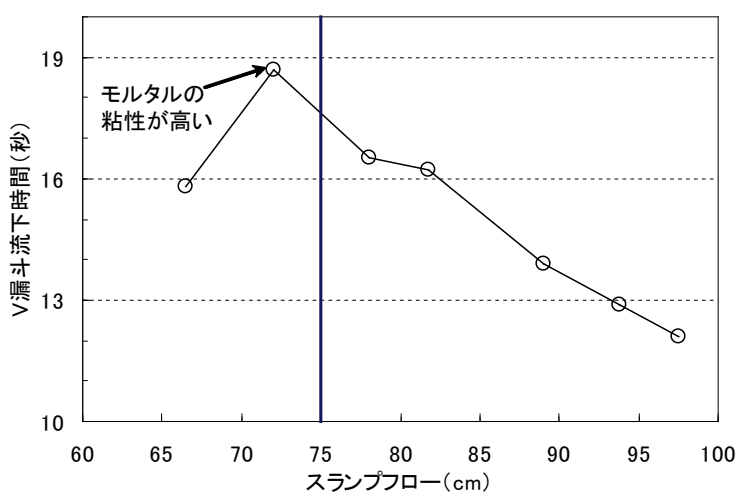

図-4 V 漏斗流下時間とスランプフロー

\section{(1) 目標スランプフローの設定}

ここでは，材料分離が生じない範囲で，充てん性と流 動性の向上を目的とした目標スランプフローの設定を行 った。 スランプフローの設定に用いる混和剤は，練混ぜ 直後のフレッシュ性状が混和剤種により有意な差異が見 られなかったことから，高性能AE減水剤（SP1）のみを 用いた. SP1の添加量を調整することにより，スランプ フローを $65 \mathrm{~cm} \sim 95 \mathrm{~cm}$ 程度の範囲で変動させて，各試験 を実施した。混和剤添加率とスランプフローの関係を図 -3に示す.

スランプフローは, 高性能AE減水剤の添加量の増加 に伴って増加した．なお，スランプフローが $90 \mathrm{~cm}$ 以上 の場合には，モルタル表面にペーストの浮きや細骨材の 沈降といった材料分離が観察された。したがって，材料 分離しない範囲として, 目標スランプフローの上限を 90cmと判断した.

図-4にV漏斗流下時間とスランプフローの関係を示寸 スランプフローが減少するとV漏斗流下時間が長くなる 傾向であった．スランプフローが72cmの場合には，V漏 斗流下時間が約19秒で，粘性の高さから流動性が損なわ れていた.

本材料はモルタルであるが，参考として併用系高流動 コンクリートのV漏斗流下時間の目標值 ${ }^{8)}$ (7〜20秒） と 比較すれば，この值はほぼ上限值である．また，スラン プフロー65cmの場合にV漏斗流下時間が短いが，理由は 不明である.これらのことから，スランプフローの下限 は75cmと判断した.

以上より，目標スランプフローを $75 \mathrm{~cm} \sim 90 \mathrm{~cm} （ 82.5 \pm$ $7.5 \mathrm{~cm})$ に設定した.

\section{（2）混和剤の流動性に関する温度依存性}

廃棄体に接寸る区画内充てん材では, 廃棄体の発熱に より，養生時の環境温度が高まることが想定される，普 通ポルトランドセメントと高ビーライト系セメントのモ ルタルについて，40～ $90^{\circ} \mathrm{C} て ゙$ 高温蒸気養生した坂部らの

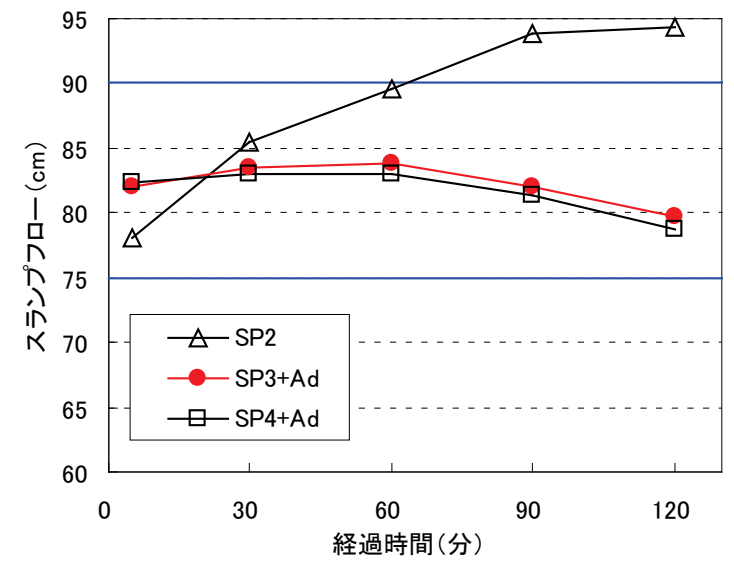

図-5 スランプフローの経時変化 $\left(20^{\circ} \mathrm{C}\right)$

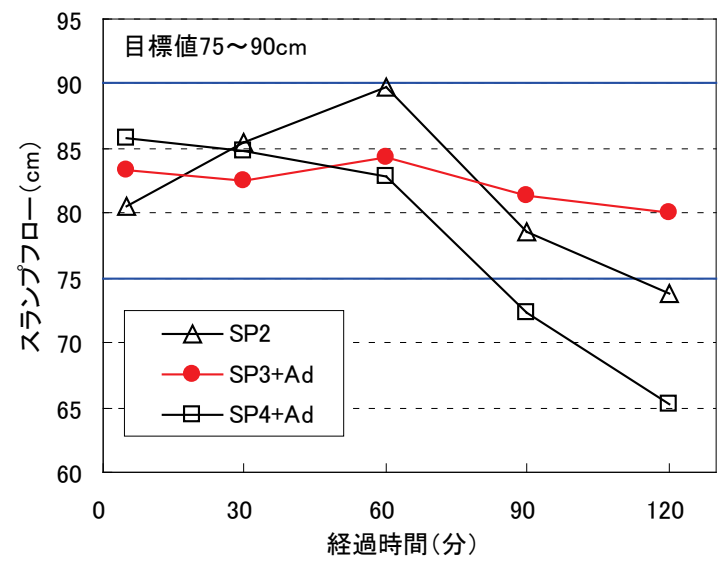

図-6 スランプフローの経時変化 $\left(60^{\circ} \mathrm{C}\right)$

研究9によれば，圧縮強度は普通ポルトランドセメント では60〜 70 Cを境に強度発現性が低下寸る傾向を示して いる.

このセメントの水和に影響を与える可能性がある温度 である $60^{\circ} \mathrm{C}$ は, 坑道の温度環境の上限值の一つの目標と なることが想定される，スランプフロー試験での環境温 度は $20^{\circ} \mathrm{C}$ およ゙ $60^{\circ} \mathrm{C}$ とた。 なお，流動性確認試験では, 施工時の温度変化等を考慮し, 環境温度 $80^{\circ} \mathrm{C}$ の試験を追 加した。ここで，流動性確認試験とは，廃棄体間隙

（15cm）と流動距離を模擬して製作した試験装置によ り，モルタルの流動性を確認する試験である.

$20^{\circ} \mathrm{C}$ 環境温度下でのスランプフローの経時変化を図5に示寸。低拡散層で使用しているSP1は予備試験で高温 環境下でのスランプフローロスが大きかったため，本試 験ではフレッシュの保持性を特徵とする混和剤（SP2， SP3，SP4）を用いて試験した。このうちSP3およびSP4 は，遅延型の減水剤を併用することで，フレッシュの経 時保持性を期待した。 $20^{\circ} \mathrm{C}$ 環境温度下では，SP3とSP4 が120分までスランプフローの変化が非常に小さく, SP2 では，スランプフローが120分まで増加し，90分後におい 


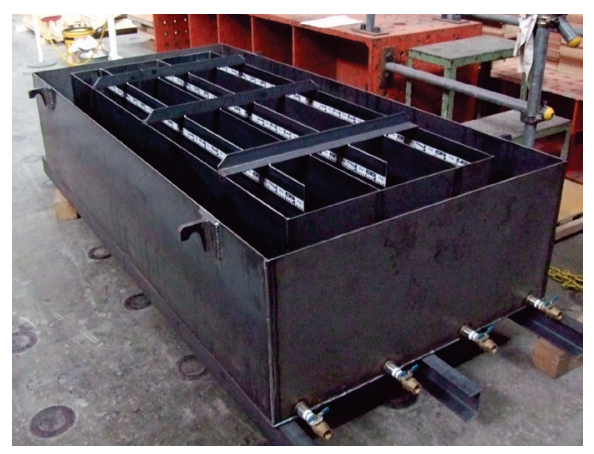

写真-2 流動性確認試験装置

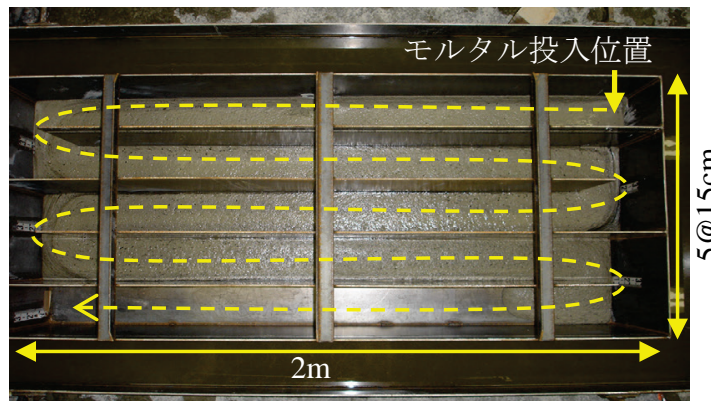

図-7 流動性確認試験状況

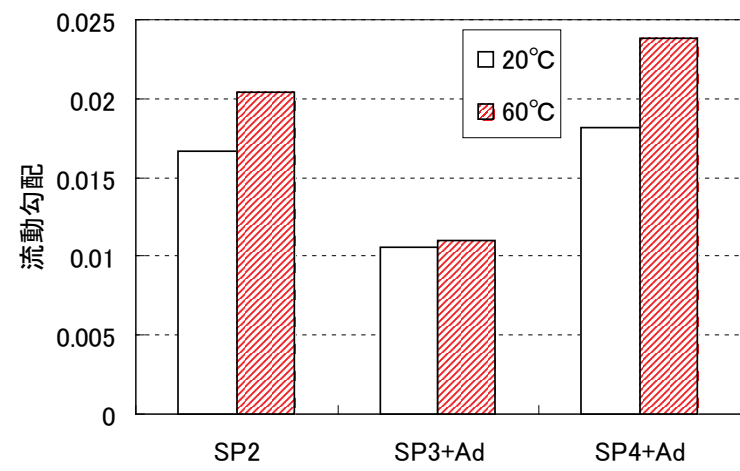

図-8＼cjkstart流動性確認試験での流動勾配

表-6＼cjkstart選定した区画内充てん材の配合

\begin{tabular}{|c|c|c|c|c|c|c|c|}
\hline \multirow{2}{*}{$\begin{array}{c}\text { W/B } \\
(\%)\end{array}$} & \multicolumn{5}{|c|}{ 単位量 $\left(\mathrm{kg} / \mathrm{m}^{3}\right)$} & SP3 & Ad \\
\cline { 2 - 6 } & W & LPC & FA & LP & S & P×\% & P×\% \\
\hline 45 & 230 & 358 & 153 & 307 & 1198 & 0.85 & 0.30 \\
\hline
\end{tabular}

スランプフロー $82.5 \pm 7.5 \mathrm{~cm}$, 空気量 $2.5 \pm 1.5 \%$

結合材 $\mathrm{B}=\mathrm{LPC}+\mathrm{FA}$

て規格值を満足しなかった.

$60^{\circ} \mathrm{C}$ 環境温度下でのスランプフローの経時変化を図6 に示す. $60^{\circ} \mathrm{C}$ の試験条件は，運搬時間や廃棄体の高温 環境を考慮した次に示寸条件とした. モルタルの練上り から 60 分までは運搬を想定した $20^{\circ} \mathrm{C}$ 環境温度下で，そ の後 120 分までは廃棄体の発熱環境を想定した温度が $60^{\circ} \mathrm{C}$, 湿度が $60 \%$ の条件である. $60^{\circ} \mathrm{C}$ 環境温度下では, $\mathrm{SP} 2$ と SP4において $60^{\circ} \mathrm{C}$ 環境温度下である 60 分から 90

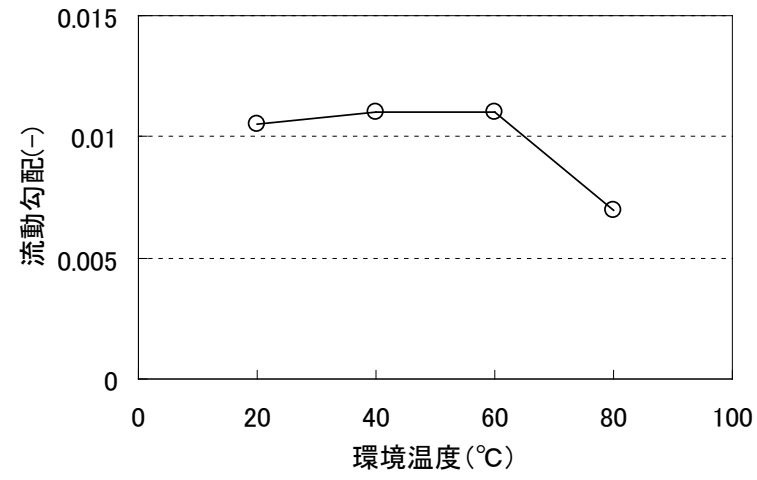

図-9＼cjkstart流動性確認試験での流動勾配

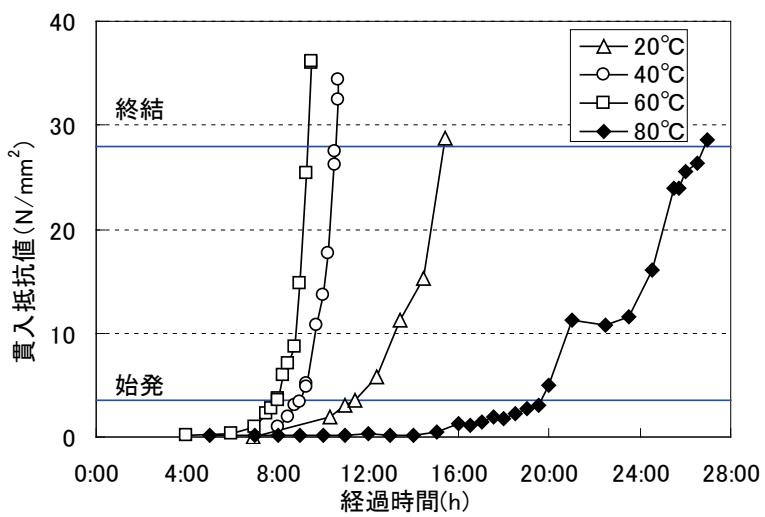

図-10 凝結時間

分の間に約 $10 \mathrm{~cm}$ 程度のスランプフローの低下があり， SP4 では規格值を満足しなかった。一方で，SP3 は高温環 境下に静置した後 60 分間でのスランプフローの低下が約 $5 \mathrm{~cm}$ と優れた経時保持性を示した.

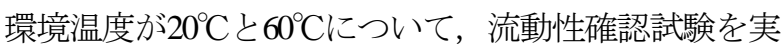
施した．試験装置を写真-2に，図-7にモルタルの流動状 況を示す。モルタルは図-7の右上に示す投入位置から 30L/分の速度で投入し，1回の試験で160Lのモルタルを約5 分間で投入した（打込み速度 $=1.8 \mathrm{~m}^{3} \mathrm{~h}$ ）。また，温水を試 験装置の外周に注水することで，任意の温度を保つ仕様 とした。

流動性確認試験による流動勾配の比較を図-8 に示寸. 流動勾配は，モルタル投入完了後，流動が停止したこと を確認し，流動距離と投入位置での充てん高さを測定し て算出した。試験時のスランプフローは 80.5 $85.0 \mathrm{~cm}$ の

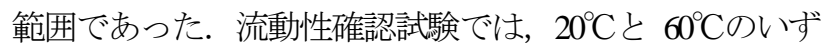
れの環境温度下でも，SP3 を使用した場合に流動勾配が 最も小さくなった．また，いずれの混和剤を用いた場合 も，200 $\mathrm{C}$ 環境温度下に比べ $60^{\circ} \mathrm{C}$ 環境温度下では流動 勾配が大きくなったが，SP3 は温度変化による影響が最 も小さかった。

以上のことから, 本試験では高性能 $\mathrm{AE}$ 減水剂 $\mathrm{SP} 3$ と 遅延型減水剂 Ad を組夕合わせて混和剤として用いる配 
合を選定した，選定した配合を表-6に示す。

選定した配合を用いた流動性確認試験を環境温度が $40^{\circ} \mathrm{C}$ と $80^{\circ} \mathrm{C}$ てい追加実施し，また同様の環境温度で 凝結試験を実施した。流動性確認試験での流動勾配を図9 に，凝結時間を図-10に示す， $20^{\circ} \mathrm{Cから} 60^{\circ} \mathrm{C}$ 範囲では, 温度が流動勾配に与える影響は非常に小さいが， $80^{\circ} \mathrm{Cで}$ は流動勾配が小さくなった。

凝結時間は $20^{\circ} \mathrm{Cから} 60^{\circ} \mathrm{C}$ 範囲では，温度が高いほど

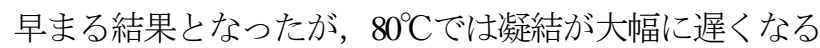
結果となった. $20^{\circ} \mathrm{Cから} 60^{\circ} \mathrm{C}$ 傾向は，高温時にセメン 卜の水和が早まる一般的な傾向であると考えられる.

遅延型の混和剤は主として，C $\mathrm{C}_{3} \mathrm{~S}$ の表面に遅延成分が 吸着し， $\mathrm{C}_{3} \mathrm{~S}$ の水和を遅らせる. この $\mathrm{C}_{3} \mathrm{~S}$ の吸着層は，水 和の進行に伴って, 次第に水和生成物中に取り込まれ水 和抑制効果を失っていく ${ }^{10)}$. $80^{\circ} \mathrm{C}$ 環境温度下で凝結時 間が遅くなった原因は，何らかの要因によりこの水和抑

表-7 硬化物性の試験方法

\begin{tabular}{|l|l|}
\hline \multicolumn{1}{|c|}{ 項目 } & \multicolumn{1}{c|}{ 方法 } \\
\hline 圧縮強度試験 & JISA1108 \\
\hline 静弾性係数試験 & JISA1149 \\
\hline 固相分析 & 鈴木・西川|13による方法を参考 \\
\hline 自己収縮試験 & JCISQA5 \\
\hline 乾燥単位容積質量 & JASS5NT-602 \\
\hline
\end{tabular}

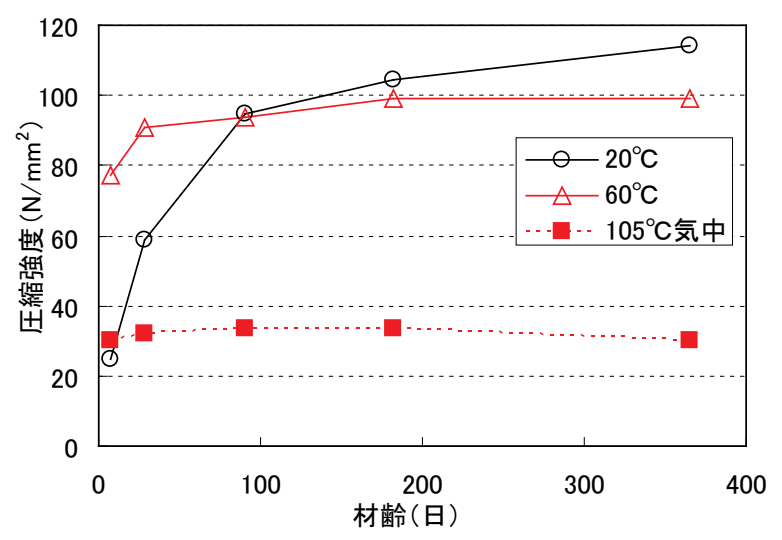

図-11 養生温度と圧縮強度（室内）

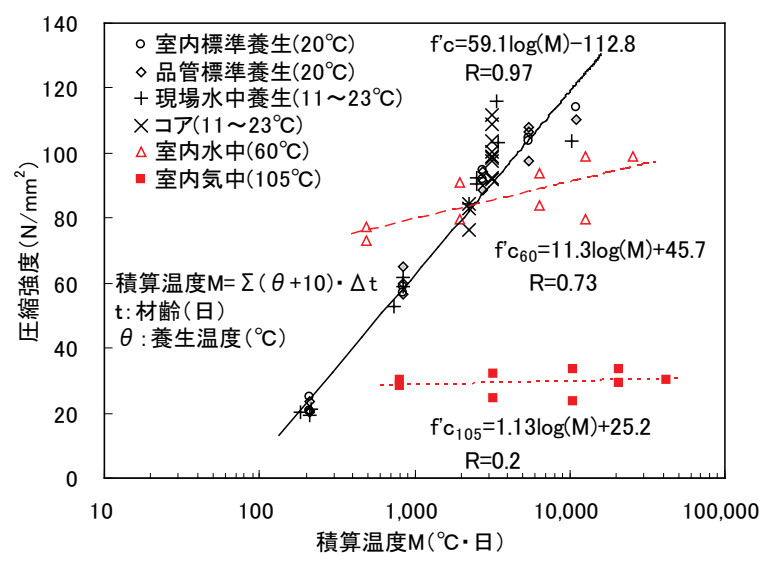

図-12 積算温度と圧縮強度
制効果が水和反応に比べて極端に卓越したことにあると 考えるが，この要因についてはさらなる検討が必要であ る.

\section{5. 高温環境で養生した区画内充てん材の硬化物 性}

高温環境で養生して圧縮強度などの硬化物性を取得し た. 試験方法を表-7 に示し，それらの結果を以下に示 す.

\section{(1) 圧縮強度}

試験室内で $20^{\circ} \mathrm{C}$ と $60^{\circ} \mathrm{C}$ で水中養生した供試体と，処 分施設の換気設備の異常等によって高温となる場合を想 定し，極端な条件として，105 $\mathrm{C}$ 環境で気中養生した供 試体での試験を実施した．試験材齢は 7，28，91，182， 365 日である。試験結果を図-11 に示す。 $60^{\circ} \mathrm{C}$ の水中養 生では， $20^{\circ} \mathrm{C}$ 水中養生と比較して早期に圧縮強度の発 現が見られ，材齢 7 日，28 日では $20^{\circ} \mathrm{C}$ の水中養生より 圧縮強度が高くなった. ただし, その後の強度発現は遅 く，材齢 91 日で $20^{\circ} \mathrm{C}$ 水中養生と $60^{\circ} \mathrm{C}$ 水中養生は同 等の值となり，182 日以降では $20^{\circ} \mathrm{C}$ 水中養生の方が高

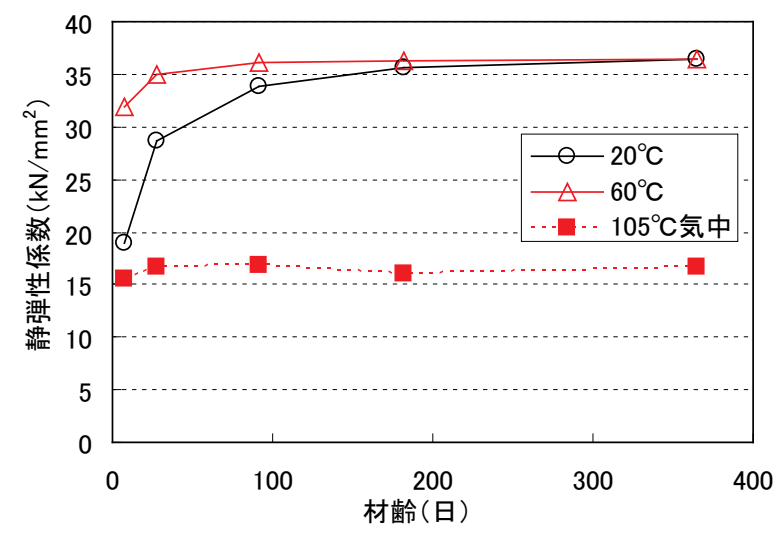

図-13＼cjkstart養生温度と静弾性係数（室内）

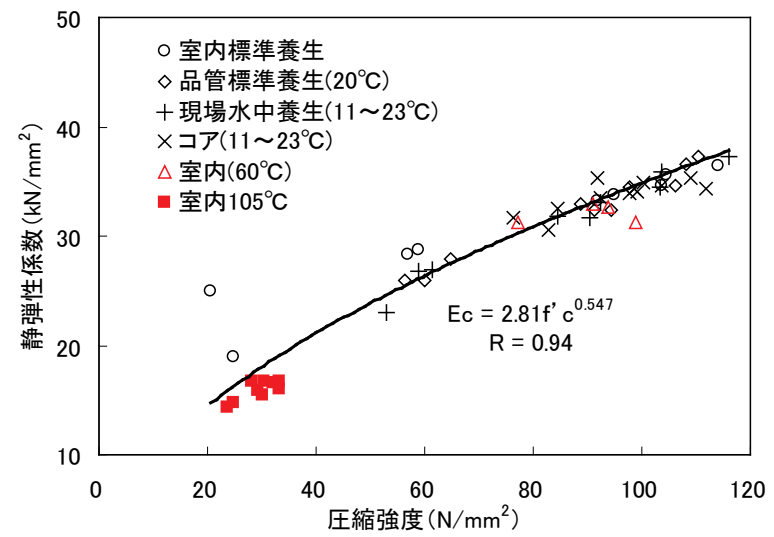

図-14 静弾性係数と圧縮強度 
い結果となった．養生温度が高い場合には初期強度が速 やかに発生する一方で，長期材齢時の強度の伸びが小さ いという傾向は，一般的な暑中コンクリートでの傾向と 同じである ${ }^{11) .}$

一方 $105^{\circ} \mathrm{C}$ 気中養生では, 若材齢から時間経過に伴 う変化は小さく, $35 \mathrm{~N} / \mathrm{mm}^{2}$ 程度の発現に留まった。 $105^{\circ} \mathrm{C}$ 気中養生での養生は乾燥炉内であることから， 水分の蒸発により水和が進行しなかったものと考えられ る. ただし，水和反応に対して著しく悪いこの条件でも， 本試験で目標とした 30N/mm² 超えることが確認され た.

本試験では，実規模試験時の品質管理として採取した 標準養生供試体（製造時にプラントで作製）と現場水中 養生供試体（現場荷卸し時に作製），構築された構造体 から採取したコア，配合選定時に採取した室内試験で作 製した供試体による試験を実施している。なお，プラン 卜，現場水中養生の品質管理供試体はいずれも同一のア ジテータ車から採取した。

これらの供試体について環境温度の履歴による積算温 度と圧縮強度の関係を，図-12に整理した。高温条件以 外の圧縮強度は積算温度と非常に強い相関が見られる。

この傾向はほぼ同じ配合である低拡散層で試験した既往 の報告3)および庭瀬らの研究 ${ }^{12}$ に示された傾向と同様で ある. 一方, 高温条件での傾向は常温環境での傾向と大 きく異なり, 養生温度が高い場合には, 圧縮強度が積算 温度の関数で一元的に表現できない可能性を示した.

\section{(2) 静弾性係数}

静弾性係数は，圧縮強度と同一供試体により試験した。 室内での試験結果を図-13 に示寸． $60^{\circ} \mathrm{C}$ 水中養生では, $20^{\circ} \mathrm{C}$ 水中養生と比較して早期に静弾性係数の発現が見 られる. その後の増加は緩やかとなり，材齢 365 日では $20^{\circ} \mathrm{C}$ 水中養生とほぼ同等の值を示した。 また, $105^{\circ} \mathrm{C}$ の気中養生では，圧縮強度と同様に，若材齢から時間経 過に伴う変化は小さかった.

圧縮強度と静弹性係数の関係について図-14 に整理し た. 静弾性係数は圧縮強度と非常に強い相関が認められ た. 養生温度が高まることで強度発現性は異なる傾向を 示寸ものの, 圧縮強度と静弾性係数の関係は保持されて いる.

\section{(3) 固相分析}

コンクリートの分析で一般に知られる鈴木・西川 ${ }^{13)} の$ 提案する方法，フライアッシュの反応率は小早川ら ${ }^{14)} の$ 方法を参考に，モルタルの固相分析を行った. 分析は， 打込みから $20^{\circ} \mathrm{C}$ と $60^{\circ} \mathrm{C}$ で 91 日養生したモルタルを対象 とした，XRD による定性結果を表-8 に，DSC と TGDTA を組み合わせて定量した結果を表-9 に示す. $60^{\circ} \mathrm{C}$
表-8 XRDによる定性結果

\begin{tabular}{|c|c|c|c|c|c|c|c|}
\hline \multirow{2}{*}{$\begin{array}{l}\text { 養生 } \\
\text { 温度 }\end{array}$} & \multicolumn{7}{|c|}{ 定性鉱物 } \\
\hline & $\mathrm{Ca}(\mathrm{OH})_{2}$ & C-S-H & $\mathrm{AFt}$ & $\mathrm{AFm}$ & $\begin{array}{c}\text { カト } \\
\text { アイ } \\
\text { 卜 }\end{array}$ & FA & $\mathrm{CaCO}_{3}$ \\
\hline $20^{\circ} \mathrm{C}$ & 0 & 0 & - & 0 & - & 0 & (?) \\
\hline $60^{\circ} \mathrm{C}$ & - & 0 & - & - & $\triangle$ & 0 & (?) \\
\hline
\end{tabular}

（）：ピーク強度が強く，含有量が多いと推測

$\bigcirc:$ ピーク強度が弱く, 含有量が少ないと推測

$\triangle:$ ピーク強度が非常に弱く, 含有量が極めて少ないか, 含 まれていないと推測

一：ピークが確認されない

$\mathrm{Ca}(\mathrm{OH})_{2}$ : 水酸化カルシウム

C-S-H : ケイ酸カルシウム水和物

$\mathrm{CaCO}_{3}$ : 炭酸カルシウム

Aft : エトリンガイト

$\mathrm{AFm}$ : モノカーボネート

主に石灰石骨材と石灰石微粉末

FA : フライアッシュ

表-9 XRD，DSC，TG-DTAによる定量結果

\begin{tabular}{|c|c|c|c|c|c|c|c|c|c|}
\hline \multirow{2}{*}{$\begin{array}{l}\text { 養生 } \\
\text { 温度 }\end{array}$} & \multicolumn{7}{|c|}{ 水和物の分析結果(\%) } & \multirow[b]{2}{*}{ CS } & \multirow{2}{*}{$\begin{array}{c}\text { FA } \\
\text { 反応摔 } \\
(\%)\end{array}$} \\
\hline & $\mathrm{Ca}(\mathrm{OH})_{2}$ & $\begin{array}{l}\text { シリカ } \\
\text { ジル }\end{array}$ & AFt & $\mathrm{AFm}$ & 付着水 & FA & C-S-H & & \\
\hline $20^{\circ} \mathrm{C}$ & 4.5 & 0.3 & 3.3 & 6.3 & 4.9 & 16.6 & 64.1 & 1.7 & 30.7 \\
\hline $60^{\circ} \mathrm{C}$ & 0.0 & 0.5 & 0.5 & 0.0 & 3.7 & 10.1 & 85.3 & 1.8 & 59.5 \\
\hline
\end{tabular}

で水中養生した場合には，20 Cで生成が確認された水酸 化カルシウム，モノサルフェートが含まれなかった.

$60^{\circ} \mathrm{C}$ で水中養生した場合には， $20^{\circ} \mathrm{C}$ 場合と比較して, フライアッシュ反応率が約 2 倍となっている. また，水 酸化カルシウムが減少し, C-S-H は増加している. 一般 に，フライアッシュを混入したモルタル・コンクリート では, フライアッシュに含まれる Si 成分が水酸化カル シウムと反応し, C-S-H が生成する. その後, さらにフ ライアッシュの反応が進み, 水酸化カルシウムが消失す ると, フライアッシュに含まれる Si 成分が C-S-H に取 り込まれる形で C-S-H のカルシウムシリカ比（C/S）が 低下していく.フライアッシュのポゾラン反応は温度依 存性が高く, 養生温度が高い場合に促進される ${ }^{14}$. 本モ ルタルも養生温度が高いことにより, フライアッシュの ポゾラン反応が促進されたと考えられる. 本試駼結果で は， $20^{\circ} \mathrm{C} ， 60^{\circ} \mathrm{C}$ ずれの養生条件においても，C/S は同 程度あるが， $60^{\circ} \mathrm{C}$ 養生条件では水酸化カルシウムが消 失している. このことから, 材齢 91 日まで $60^{\circ} \mathrm{C}$ 水中養 生した試料は, フライアッシュの反応が進み, 水酸化カ ルシウムが消失した直後の状態であったと推察される.

\section{（4）乾燥単位容積質量}

試験方法は，コンクリートの乾燥単位容積質量試験方 法（JASS5N T-602）に準拠した. 試験は $105^{\circ} \mathrm{C}$ 乾燥炉 にて 3 日間の質量減少が $0.5 \mathrm{~g}$ 以内になるまで乾燥させ, その質量を計測するものであり ${ }^{4}, \quad \phi 100 \times 200 \mathrm{~mm}$ の円柱 
供試体とした. 約 4 か月の乾燥の結果，本モルタルの乾 燥単位容積質量 $2.119 \mathrm{t} / \mathrm{m}^{3}$ が得られた. JASS5N では, 乾 燥単位容積質量はフレッシュコンクリートの単位容積質 量と相関があり, 乾燥単位容積質量は単位容積質量に対 して $0.1 \mathrm{t} / \mathrm{m}^{3}$ 程度低いことが示されている4．本モルタル のフレッシュな単位容積質量は $2.246 \mathrm{t} / \mathrm{m}^{3}$ でその差は $0.127 \mathrm{t} / \mathrm{m}^{3}$ であり，これと同様の傾向を示した.

JASS5N における乾燥単位容積質量の設計值は, 標準 偏差の 3 倍を下回らないように設定される゙4. 例えば九 州電力玄海 4 号原子力発電所では, データ数が 173 個の 乾燥単位容積質量の平均值は $2.244 t \mathrm{~m}^{3}$, 標準偏差は $0.014 t / \mathrm{m}^{3}$ に対して, 設計乾燥単位容積質量は $2.18 \mathrm{t} / \mathrm{m}^{3}$ が 与えられている4). 本モルタルでの乾燥単位容積質量の 設計值は $2.0 t \mathrm{~m}^{3}$ 程度が目安となるものと考えるが，設計 值を設定するに当たっては，今後データを蓄積する必要 がある。
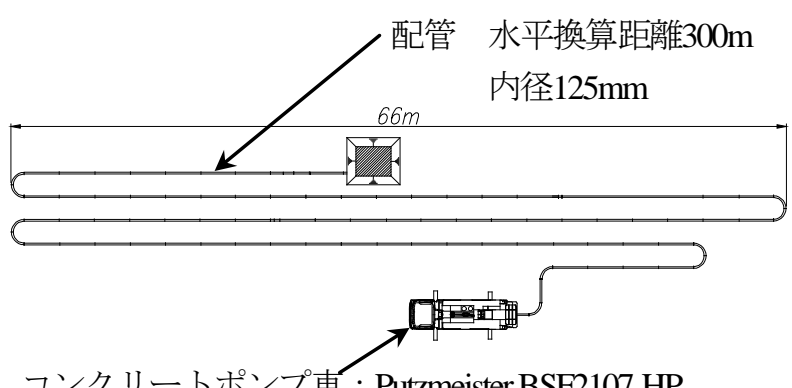

図-15 圧送試験の概要

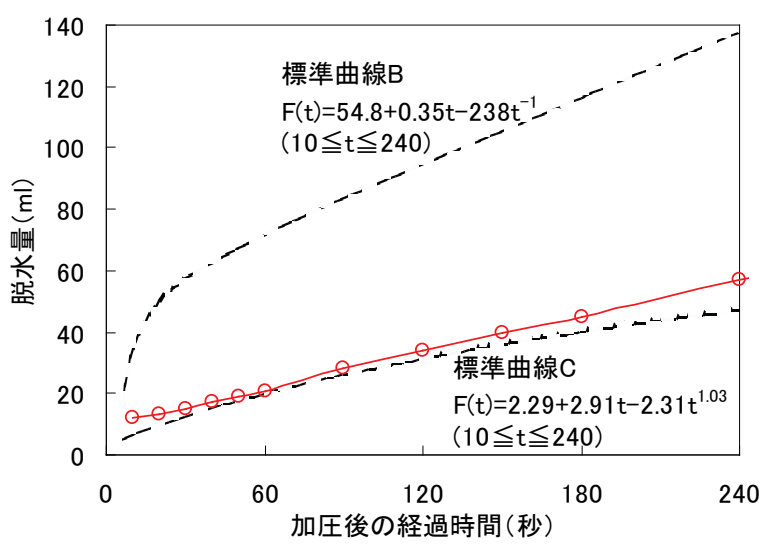

図-16 加圧ブリーディングの比較 ${ }^{16}$

表-10 ポンプ圧送試験で併用した試験方法

\begin{tabular}{|l|l|}
\hline \multicolumn{1}{|c|}{ 項目 } & \multicolumn{1}{c|}{ 方法 } \\
\hline 加圧ブリーディング & JSCE-F502 \\
\hline スランプフロー & JIS A1150 \\
\hline 漏斗流下時間 & $\begin{array}{l}\text { JSCE-F512 モルタル用 } \\
\text { (排出口 30×30mm) }\end{array}$ \\
\hline 空気量 & JIS A1128 \\
\hline 単位容積質量 & JIS A1116 \\
\hline
\end{tabular}

\section{6. ポンプ圧送試験結果}

区画内充てん材は，図-2に示したようにアジテータ車 からの荷卸し場所から施工場所まで150～250m程度の場 内運搬が想定される. 本試験ではモルタルのポンプ圧送 性を確認することを目的に，圧送管を水平換算距離 ${ }^{15)}$ $300 \mathrm{~m}$ となる長さに配置して圧送試験を実施した。試験 には，世界最大級の圧送能力を持つポンプ車

(Putzmeister BSF2107-HP : 最大吐出圧力22.0MPa) を用い, 図-15のように配置した。試験配合は，室内試験により 選定した表-6に示寸ものである.

事前に室内で実施した加圧ブリーディング試駼結果を，

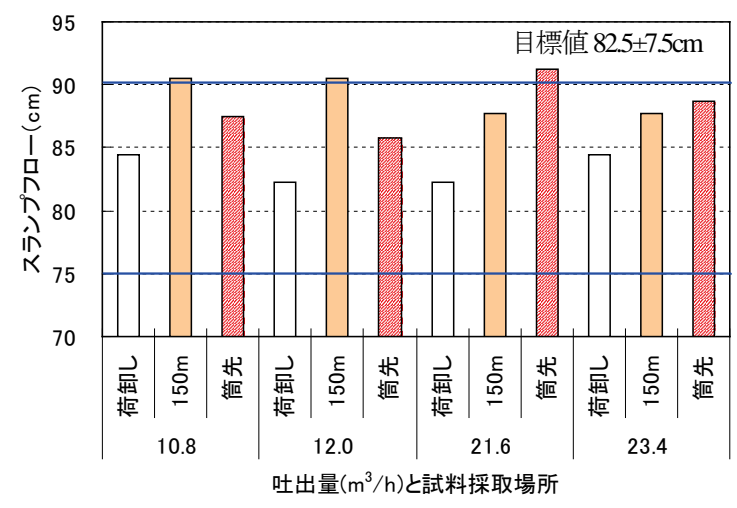

図-17 圧送前後のスランプフロー

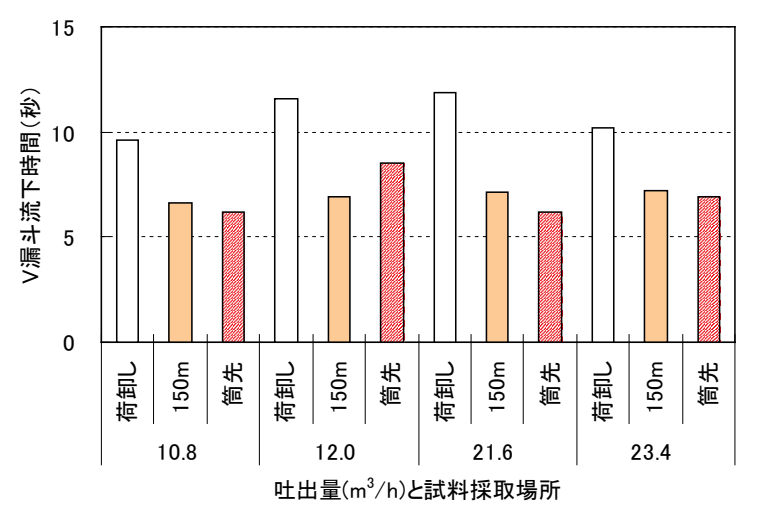

図-18 压送前後のV漏斗流下時間

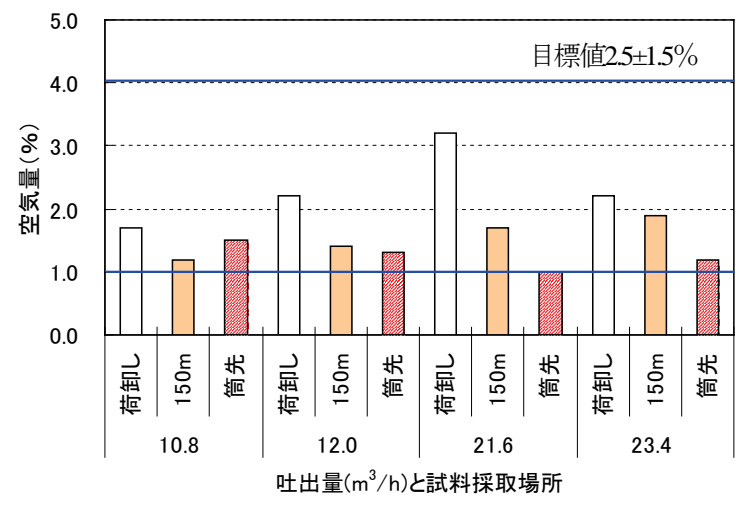

図-19 圧送前後の空気量 


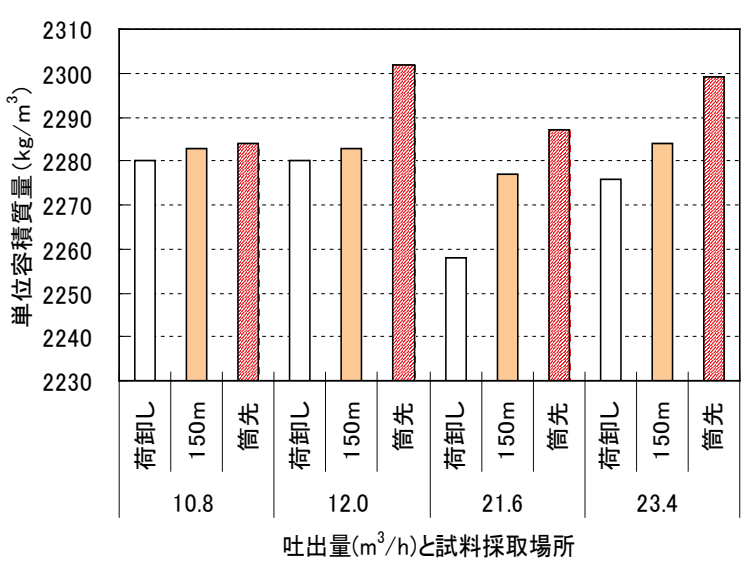

図-20 圧送前後の単位容積質量

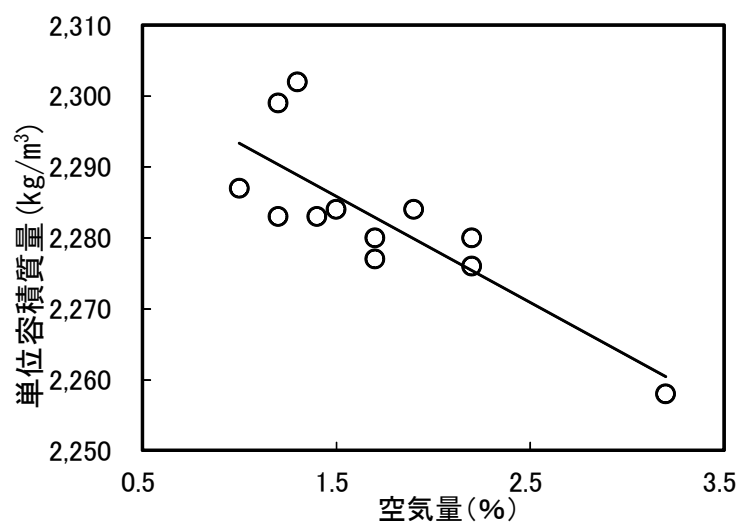

図-21 空気量と単位容積質量

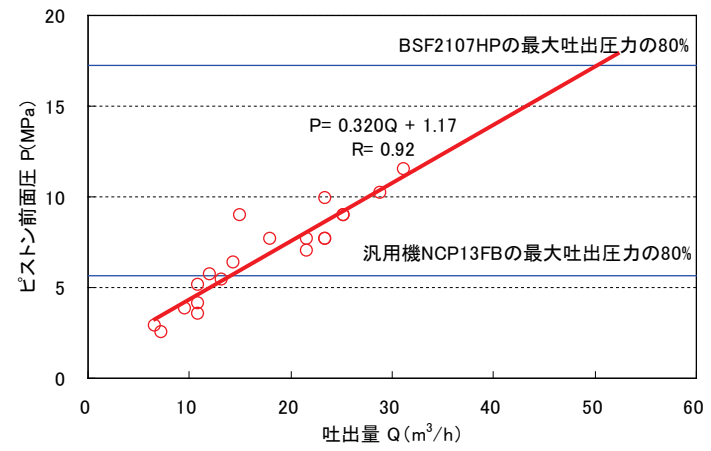

図-22 吐出量とポンプ車のピストン前面圧

土木学会指針 ${ }^{15)}$ で示される標準曲線と併せて図-16に示 す. 加圧ブリーディング試験は，フレッシュコンクリー トのポンプ圧送性を評価する試験方法であり，標準曲線 内であれば，ポンパビリティーが良好な条件とされるも のである. 図により, 標準曲線内に入ることが示され, 本モルタルのポンパビリティーは良好と考えられる.

圧送試験は，吐出圧と圧送性の確認を目的として，吐 出量を6 31 $\mathrm{m}^{3} / \mathrm{h}$ に変化させた。 吐出量は筒先付近に配 置した流量計（明昭(株)MGR2000A-100）で計測した. 試験方法を表-10に示す．試験はアジテータ車からの荷
卸し時と水平換算距離が $150 \mathrm{~m}$ の位置および筒先での試 料を用いて実施した．水平換算距離が150mの位置の試 料は，該当位置にバルブを設けて圧送中に採取した。試 料は，吐出量が少なめ $\left(10.8 \mathrm{~m}^{3} / \mathrm{h}, 12.0 \mathrm{~m}^{3} / \mathrm{h}\right)$ の時点と多 め $\left(21.6 \mathrm{~m}^{3} / \mathrm{h}, 23.4 \mathrm{~m}^{3} / \mathrm{h}\right)$ の時点でそれぞれ採取した.

図-17に圧送前後のスランプフローを示す，荷卸し時 のスランプフローは目標值を満たしたものの，圧送後の スランプフローはいずれも上昇して，一部で目標值を少 し上回った．スランプフローは吐出量が少ない場合には, 水平換算距離が150mで大きく，吐出量が多い場合には， 筒先で大きくなった．図-18には圧送前後のV漏斗流下 時間を示す。V漏斗流下時間は圧送後に小さくなった。

モルタルの塑性粘度は，ポンプ圧送後に低下寸る傾向 を示寸場合がある16. 本モルタルにおけるスランプフロ 一とV漏斗流下時間の圧送後の傾向も, 塑性粘度の低下 がスランプフローの上昇とV漏斗流下時間の低下に影響 を与えたと推察される.

図-19に圧送前後の空気量を，図-20に圧送前後の単位 容積質量を示す，圧送後の空気量は小さくなり，単位容 積質量は大きくなった，空気量の減少は，圧送によりモ ルタルが圧縮されたためと考えられる．図-21に単位容 積質量と空気量の関係について整理した. 単位容積質量 は空気量の減少と相関があると考えられる。遮へい性能 が要求される区画内充てん材においては, 質量は大きい 方が望ましく, 単位容積質量の増加はむしろ良い傾向で あると考える。

吐出量とポンプ車のピストン前面圧の関係を，図-22 に整理した．土木学会指針15によれば，ポンプ車が圧送 可能と判断する限界は最大理論吐出圧力の $80 \%$ を基準と している．図には，本試験で使用したポンプ車と一般に 高出力機種として使用される汎用機（ニイガタ NCP13FB-364 : 最大吐出圧力7.1MPa) の最大吐出圧力の 80\%を図示した.

図に示寸ように，ポンプ車の前面圧は吐出量の増大と ともに大きくなった，汎用機では，吐出量 $14 \mathrm{~m}^{3} / \mathrm{h}$ 程度で 圧送限界となり，施工量が制限されるが，超高圧タイプ のポンプ車を用いれば，圧送可能であることが示された。 ただし，超高圧タイプのポンプ車は国内で数台の希少機 種であることに注意が必要となる.

\section{7. 実規模充てん性確認試験結果}

区画内充てん材の実規模試験は，図-23の断面図で示 すように，試験の目的に応じた3つのブロックで実施し た．試験は，充てん性を確認することを目的とした場内 運搬方法として(1)ポンプ車を用いた試験と，(2)移動式 バケットを模擬した試験並びに(3)打込み時の側圧が他 部材へ与える影響を確認することを目的として打込み高 


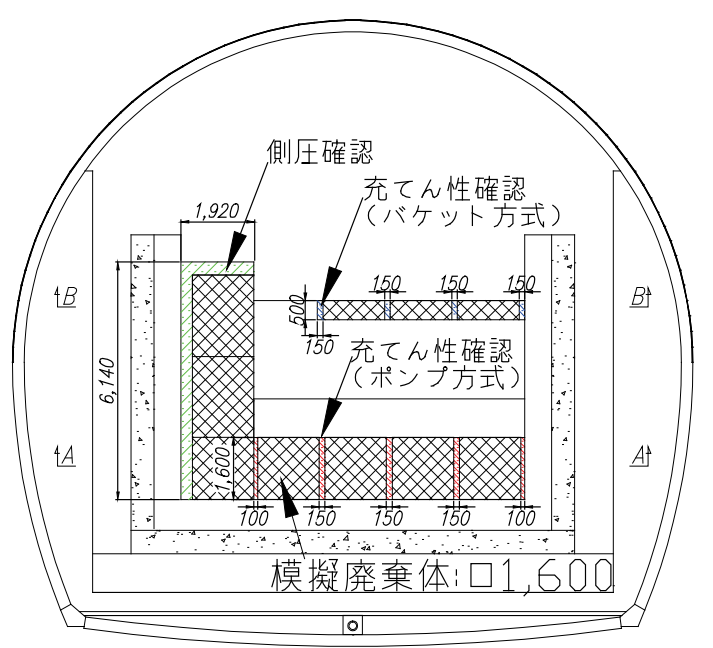

図-23 実規模試験断面図

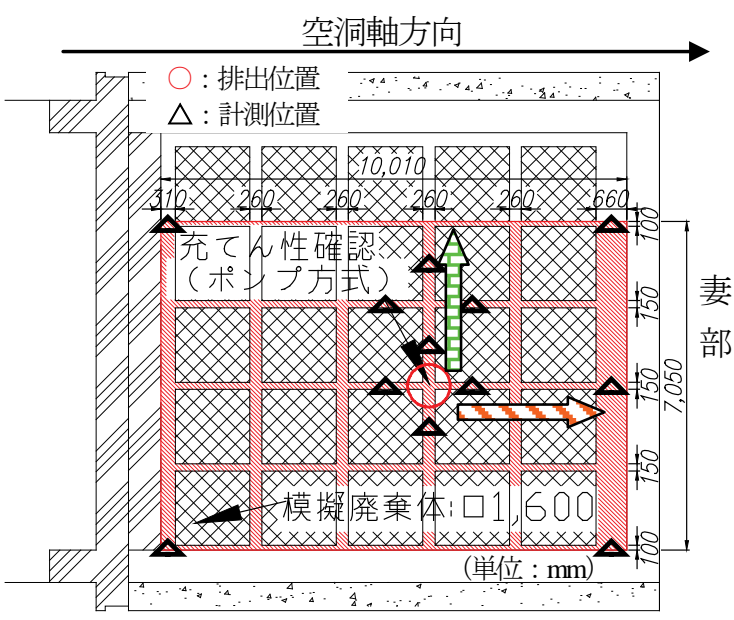

図-24 ポンプ方式による充てん性確認試験平面図(A-A)

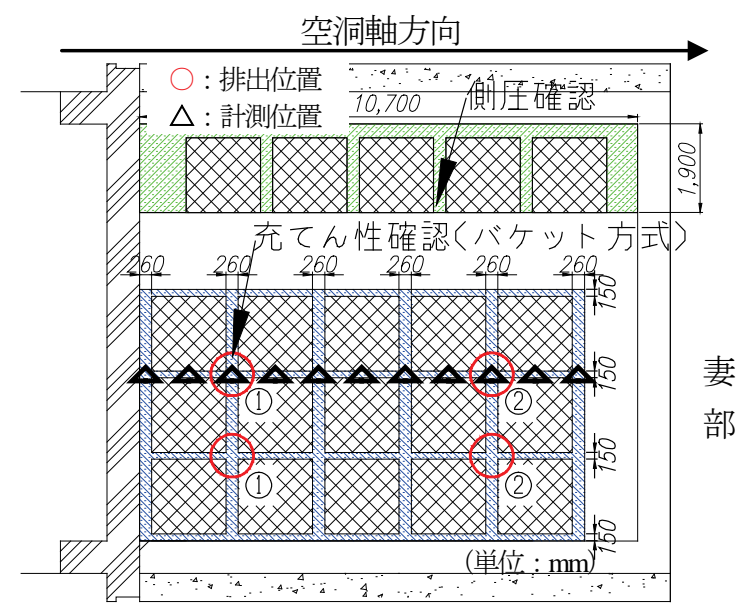

図-25移動式バケット方式模擬，側圧確認試験平面図(B-B)

さを模擬した試験である．図-24と図-25に平面図を示す．

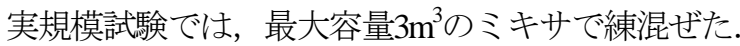
練混ぜ時間と投入材料は次のとおりである. $<$ 空練り 30 秒 $\rightarrow$ 水 $(+$ 混和剂) 投入後 90 秒練混ぜ $\rightarrow モ ル タ$ 儿排出 $>$

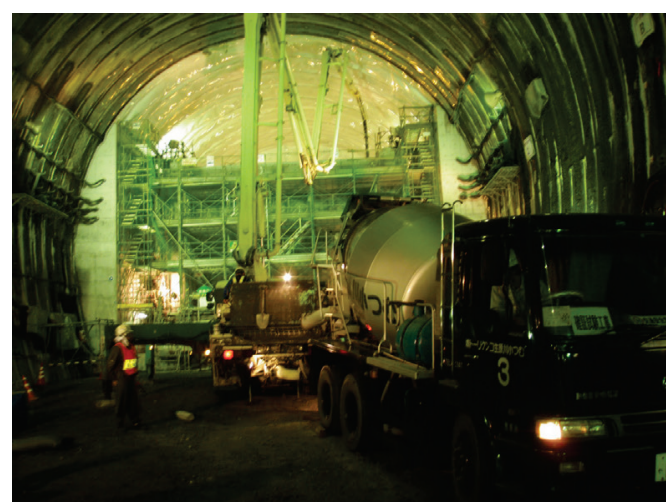

写真-3 ポンプ方式の状況

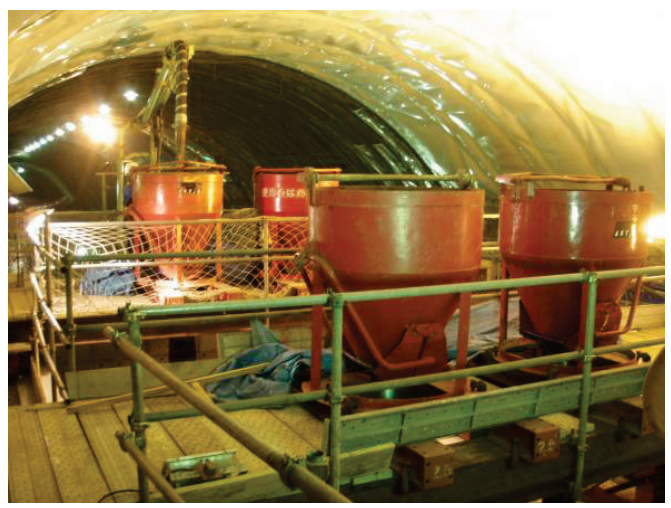

写真-4 バケット方式の状況

\section{（1） 充てん性確認試験（ポンプ方式）}

廃棄体間の間隙に対する充てん性を確認するに当たり， 模擬廃棄体を製作し定置した。隣り合う模擬廃棄体の間 隔は空洞の軸方向には260mm，横断方向には $150 \mathrm{~mm}$ と た。模擬廃棄体は一辺が $1.6 \mathrm{~m} の$ 立方体であり，厚さが $9 \mathrm{~mm}$ 鋼製の外枠に普通コンクリートを充てんしたもの である。

区画内充てん材の打込みにはコンクリートポンプ車 （ニイガタ製NCP11FB-324）を用い，吐出量を9.2〜 $24 \mathrm{~m}^{3} / \mathrm{h}$ に変化させて，図-24中の○部の位置から打ち込ん だ。また，レーザー距離計(DIMETIX製DLS-B15)を各所 に設置し，流動の状況をリアルタイムに計測した．打込 み状況を写真-3に示す．模擬廃棄体の定置状況および打 込み完了時の写真は, 本稿冒頭に示した写真-1のとおり である。

図-24中の矢印の経路の流動勾配を図-26に示寸，打込 み時のスランプフローは76〜82cm（目標值70～90cm） である，間隙幅が広い $(260 \mathrm{~mm})$ 経路では，吐出量の増大 とともに，流動勾配が小さくなった．これは吐出量が増 えることで，モルタルを押し流寸力が増大され，流れが 加勢されたことによると考えられる。しかし，間隙幅が 狭い(150mm)経路では，吐出量によらず流動勾配はほぼ 一定となった．この要因には，間隙幅の異なる経路が交 


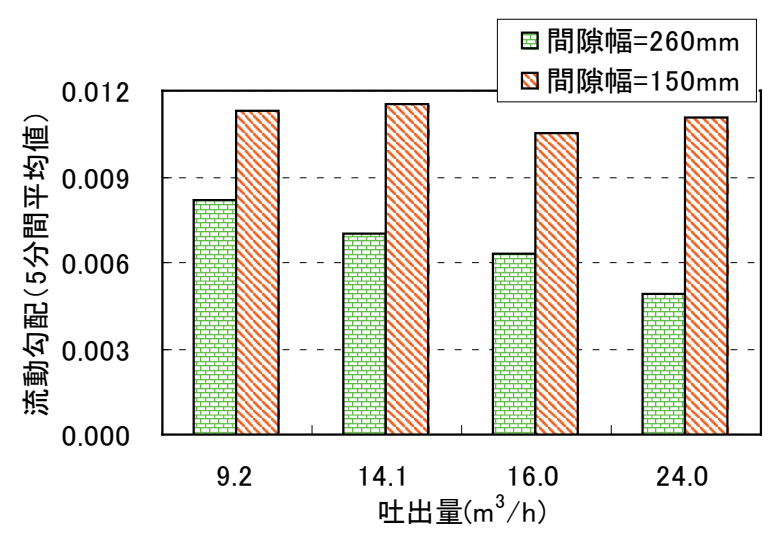

図-26 吐出量と流動勾配

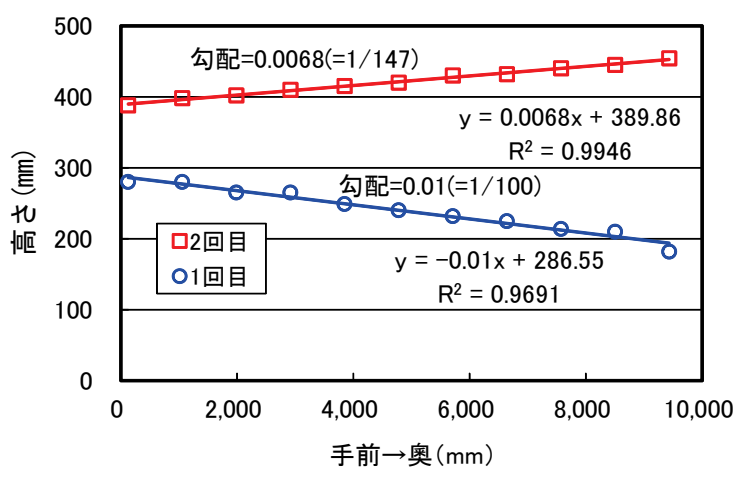

図-27 バケット方式による流動勾配

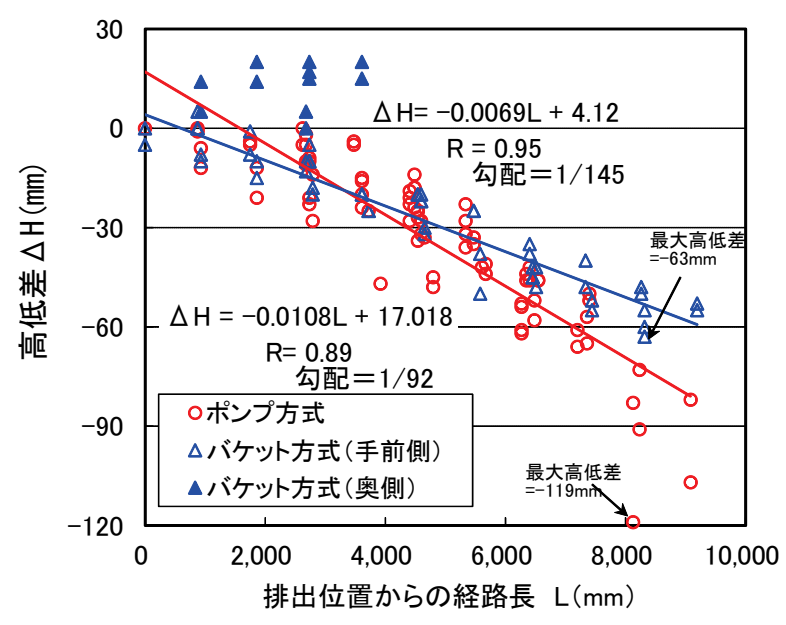

図-28 硬化後の高低差

差している場合には間隙幅の広い流れやすい経路を優先 して流れること，充てん材が押し流される力と充てん材 と模擬廃棄体との摩擦力が釣り合い，間隙幅間の流量が 定常状態となっていることが推察される.

\section{（2）充てん性確認試験（バケット方式）}

バケット方式による試験は，二つの排出口を持つ移動 式バケットが，坑道の軸方向（図-24と図-25を参照）に 移動して排出することを模擬している. ここでの模擬廃
棄体は，普通コンクリートを現場で打ち込んで製作し， 間隙幅は前記と同様に260mmと150mmとした．移動の模 擬は，コンクリート用バケットを図-25と写真-4に示す ように4個配置して順番に排出することで模擬した。 バ

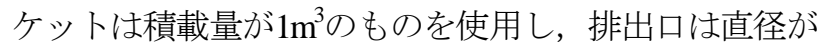
300mmの円になるように加工した.

打込み順序は，図-25中に示す1（図中では丸数字）の

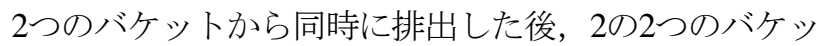
卜から排出した。 バケット 1 の打込み量は $1.78 \mathrm{~m}^{3} \times 2$, バ ケット 2 は $1.34 \mathrm{~m}^{3} \times 2$ であり, バケット 1 の排出速度は $477 \mathrm{~m}^{3} / \mathrm{h}$ ，バケット2は16.5 69.5 $\mathrm{m}^{3} / \mathrm{h}$ である. バケット $1 の$ 排出速度はバケットの排出口が全開時の排出速度であり, バケット2は打込み量の調整のために排出口を絞った結 果である. 打込み時のスランプフローは， $83 \sim 89 \mathrm{~cm}$ （目標值70 90cm）であった.

図-25の平面図の $\triangle て ゙$ 示した位置で測定した1回目と, 2回目の排出後の高さを図-27に示す. 排出されたモルタ ルは排出位置と近い側の壁際が高く，遠い側の壁際まで 一定の勾配がついている. 排出位置よりも壁際が高い理 由として, 排出されたモルタルが排出位置の周囲に充て んされた後，充てん量の少ない逆側の壁へ向かって流動 したことが考えられる．また，2回目の打込みにより高 低差は逆転し, 1回目の勾配よりも2回目の勾配が小さく なった.このことから，バケットの移動（排出位置）と 排出量の適切な管理により, 仕上がり面の高低差は低減 させることが可能と考える.

図-28には，硬化後に測定したモルタル高さを，排出 位置直下の高さとの差として経路長で整理した．測定位 置は，間隙の交差部およびその中点である．ポンプ方式 の勾配（1/92）とバケット方式1回目の勾配（1/100）は, 排出速度が大きく異なるにもかかわらず，ほぼ同じとな った．筆者らは，同様のモルタル（低拡散層）を用いて 幅が70cmを対象とした壁部材に打込みを行った結果と して，排出速度を大きくした場合に流動勾配が低減する ことを報告している゙．しかしながら，本試験のような 間隙幅，間隙の配置条件では，モルタルの流動性は，排 出速度よりもモルタル自体の流動性と排出位置の移動に よる影響が強く作用するものと考えられる.

ポンプ方式の勾配とバケット方式1回目の勾配は，室 内で実施した流動性確認試験 $\left(20^{\circ} \mathrm{C}\right)$ の勾配 $(1 / 95)$ と も同程度であり，排出条件が異なるこれらの勾配が同程 度であることから，このモルタル材料が持つ流動性の指 標としての勾配は $1 / 100$ 程度と考えることができる．ま た, 排出位置を移動させたバケット方式での高低差の最 大值は63mmであり, ポンプ方式では119mmであったこ とから，56mm低減された。 


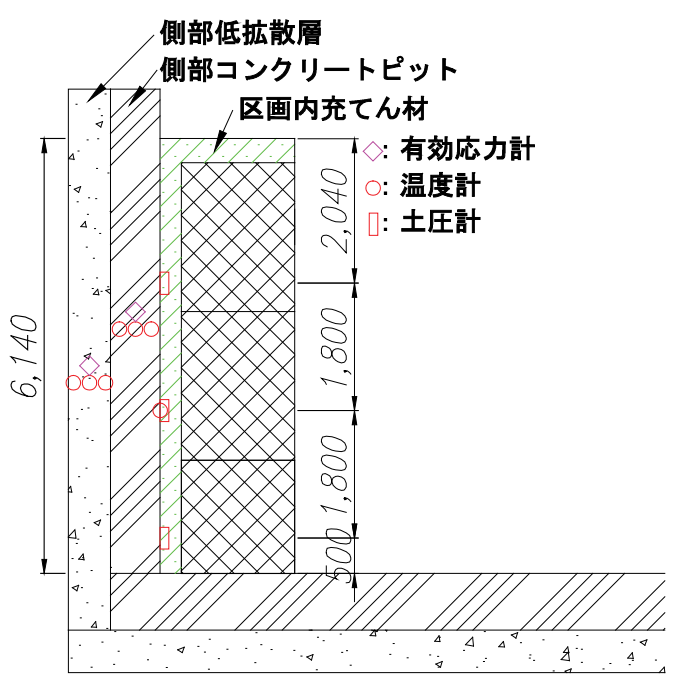

図-29 計測器位置（部材中央付近の断面）

表-11 計測器の仕様

\begin{tabular}{|l|l|l|}
\hline \multicolumn{1}{|c|}{ 計測器 } & \multicolumn{1}{c|}{ 型式 } & \multicolumn{1}{c|}{ 測定範囲 } \\
\hline 有効応力計 & GK-10N-505 & $10 \mathrm{~N} / \mathrm{mm}^{2}$ \\
\hline 土圧計 & GE400kpB-B & $400 \mathrm{kPa}$ \\
\hline 温度計 & RT-100 & $-10 \sim 80^{\circ} \mathrm{C}$ \\
\hline
\end{tabular}

※ : 計測器は全て(株)東横エルメス製

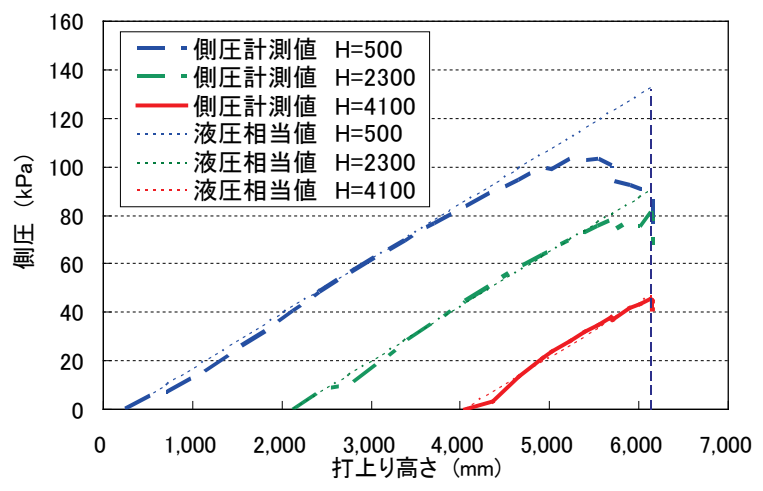

図-30 打込み時の側圧

表-12 側圧の関連データ

\begin{tabular}{|c|c|c|c|c|c|c|}
\hline 位置 & $\begin{array}{c}\text { 液圧 } \\
\text { 相当值 } \\
{[\mathrm{A}] \mathrm{kPa}} \\
\end{array}$ & $\begin{array}{c}\text { 側圧 } \\
\text { 最大值 } \\
{[\mathrm{B}] \mathrm{kPa}} \\
\end{array}$ & $\begin{array}{c}\mathrm{B}] \\
{[\mathrm{A}]} \\
\% \\
\end{array}$ & $\begin{array}{l}\text { 最大ま } \\
\text { での時 } \\
\text { 間 min } \\
\end{array}$ & $\begin{array}{l}\text { 打込み } \\
\text { 速度 } \\
\mathrm{m} / \mathrm{hr} \\
\end{array}$ & $\begin{array}{l}\text { 凝結 } \\
\text { 始発 }\end{array}$ \\
\hline 上段 & 46 & 45 & 98 & 140 & 0.87 & \multirow{3}{*}{ 11:24 } \\
\hline 中段 & 87 & 81 & 93 & 200 & 1.15 & \\
\hline 下段 & 127 & 103 & 81 & 190 & 1.67 & \\
\hline 低拡散層 & 169 & 68 & 40 & 130 & 1.85 & 7:25 \\
\hline ピット & 132 & 72 & 54 & 90 & 2.51 & 7:55 \\
\hline
\end{tabular}

注 1)液圧相当值 : 計器位置における打込み完了時点の高さ 相当の液圧計算值, 注 2)最大までの時間 : 打込み面が計器 高さに達してから側圧最大值となるまでの時間，注 3)打込 み速度 : 計器位置から最大側圧值となるまでの打込み面の 上昇速度，注 4)低拡散層 : 左側側部低拡散層下段 ${ }^{20)}$, 注 5) ピット : 側部コンクリートピット下段 ${ }^{20)}$, 注 6)凝結始発 : 凝結の始発時間20)

\section{（3）打込み時の側圧が他部材へ与える影響}

区画内充てん材の打込み時の側圧が側部コンクリート ピットや側部低拡散材へ与える影響を確認することを目 的に，高さが $6.14 \mathrm{~m}$ の部材に一括打込みを行った。図-29 に充てん時の側圧測定用の土圧計と，側部コンクリート ピット，側部低拡散層の計測器の位置を示す．計測器の 仕様は表-11に示すとおりである.

図-30に土圧計による側圧測定結果を示す。図には, 側圧が液圧で作用するものとした計算值を併せて示した。 測定した側圧は，同様の高流動モルタル，高流動コンク リートで試験した既往の報告 ${ }^{17), 18)}$ と同様に，一定時間ま では液圧で作用し，その後落ち着く傾向にある．側圧值 と関連があるデータを，表-12に示す．中段と下段の側 圧は，打込み面が計測器に達した190〜200分後に最大值 に達し，計算した液圧相当值の81～93\%程度となる．上 段と中段の液圧計算值と測定值との割合の差の要因は, 最大值に達する時間までに上昇する打込み高さが異なる ことが影響していると考えられる。上段では，打込み終 了まで液圧で作用しているが，落ち着く時間前に打込み 面が最上部に達したためと言える.

表-12に示すように，区画内充てん材は，低拡散層， コンクリートピットよりも液圧で作用する時間が長い. これは，区画内充てん材には遅延型減水剂を配合してお り，凝結の始発時間が約4時間長かったことが影響して いる.

コンクリート標準示方書【施工編】 ${ }^{19)}$ では，高流動コ ンクリートの型枠は「原則として，液圧として設計しな ければならない」と規定されている，遅延型の混和剂を 用いた場合や冬期施工など凝結が遅い場合には特に，液 圧での設計が必須となる.

側部コンクリートピットと側部低拡散層の計測器に よる測定結果を図-31〜図-34に整理した. 区画内充てん 材の打込みに要する時間は4時間50分であり，打込み時

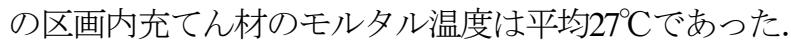

図-31に側部コンクリートピットと側部低拡散層に埋 設した有効応力計による軸方向の応力を示す. 側部コン クリートピットの応力は打込み終了時まで引張側に遷移 する. その後, 応力は圧縮側に移行し, その応力は打込 み時よりも大きくなる．側部低拡散層の応力は，打込み 開始から打込夕終了以降も引張側を示す。

図-32に側部コンクリートピットの温度データを，図33に側部低拡散層の温度データを示す. 区画内充てん 材の打込み開始からコンクリート温度が上昇した。この 温度上昇は区画内充てん材の水和によるものと考えられ， 内側の区画内充てん材側が高温になった。 ここで, 区画 内充てん材に近い側部コンクリートピット内側と側部低 拡散層外側の温度差について，図-34に整理した。温度 差は打込み開始から大きくなり，打込みから2日後には 


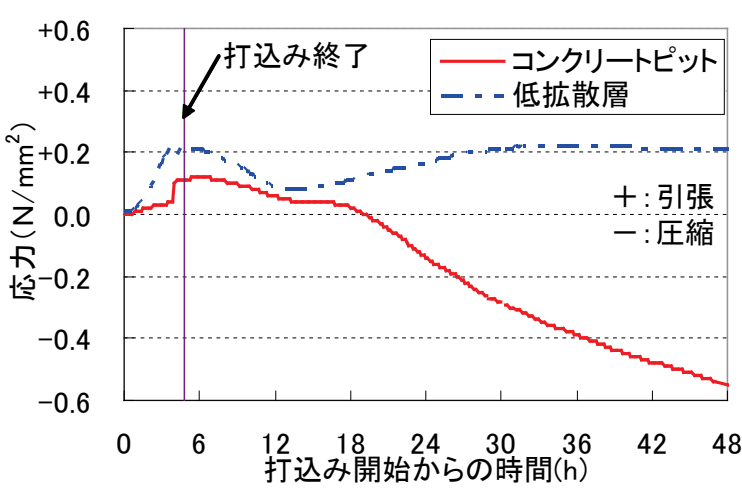

図-31 部材軸方向の応力

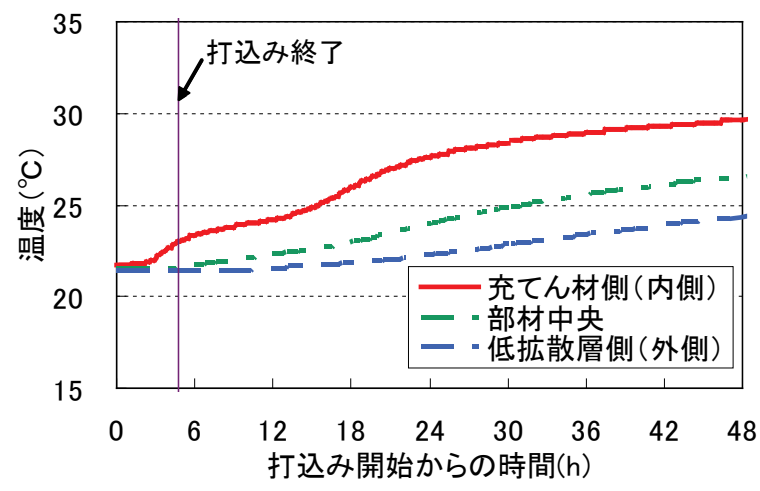

図-32 側部コンクリートピットの温度

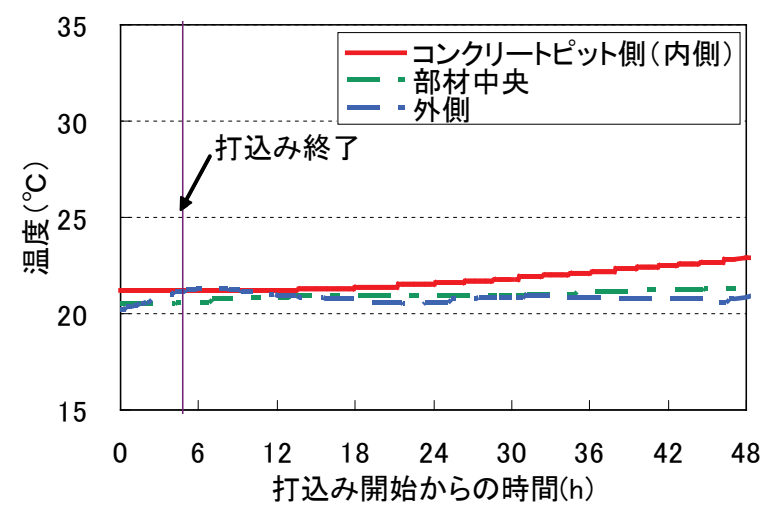

図-33 側部低拡散層の温度

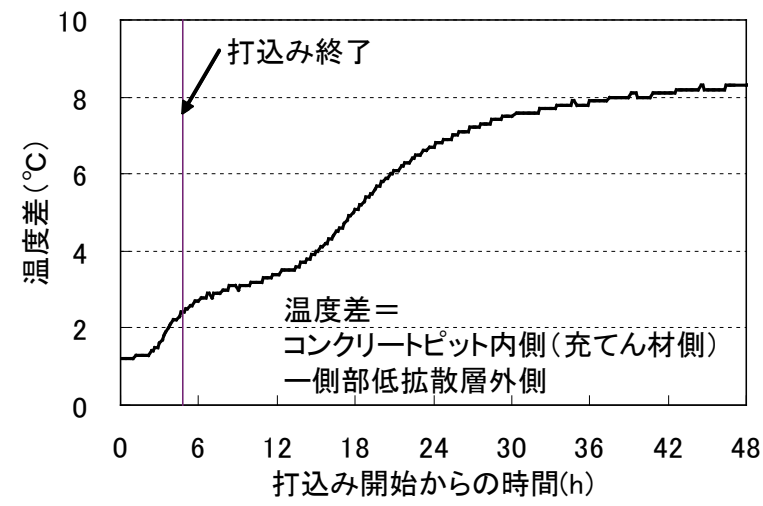

図-34 部材横断方向の温度差
落ち着いた。また，温度差は約5日後に最大值の $8.5^{\circ} \mathrm{Cを}$ 示した.

側部コンクリートピットに生じる応力変化は打込み時 と比較して，打込み終了後の方が大きい. 区画内充てん 材の打込みによる影響は，側部コンクリートピットの応 力と温度上昇の傾向を見れば，側圧による影響は小さく， 打込み後の温度による影響が大きいと言える．側部コン クリートピットに生じる応力は打込み終了以降に温度応 力による圧縮力が支配的であり，側部低拡散層の応力は 引張側を示す.

以上のように，区画内充てん材の打込みにより，側部 低拡散層はひび割れを引き起こす側に応力が作用する. 側部低拡散層の応力は打込み直後と33時間後に $0.22 \mathrm{~N} / \mathrm{mm}^{2}$ を示すが，側部低拡散層の引張強度は材齢7日

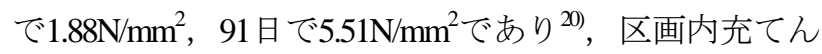
材の施工が，側部低拡散層のひび割れの主要な因子とは ならないものと考える.

\section{8. まとめ}

地下空洞型放射性廃棄物処分施設の設計と建設に向け， 大断面の地下空洞を利用した，具体的な処分施設を模擬 した施設の施工に関わる試験を実施している。このうち 本稿は，廃充体の周囲に充てんされる区画内充てん材に ついて示したものである. 本試験で得られた知見は, 次 のとおりである.

1) 廃棄体の発熱を想定した $60^{\circ} \mathrm{C} の$ 高温環境条件で も，充てん性が損なわれない区画内充てん材の 配合を選定した。

2) 高温環境での圧縮強度は，20 環境の発現性と 異なる傾向を示すが， $105^{\circ} \mathrm{C} の$ 養生条件でも材齢 91日で33N $/ \mathrm{mm}^{2}$ を示し，目標圧縮強度の30N/mm² を超えた。

3）実際の配管長を想定したポンプ圧送試験により, 超高圧タイプのポンプ車を用いれば，区画内充 てん材は圧送可能であることが示された.

4) 充てん性を確認する実規模試験では，排出位置 の移動により高低差を低減することができた. 排出速度や排出方法が区画内充てん材の流動勾 配に与える影響は小さく，充てん性の向上のた めには排出位置を移動させることが有効である.

5) 区画内充てん材の打込みが，隣接部材である側 部コンクリートピット，側部低拡散層に与える 影響は，打込み時の側圧よりもその後に発生す る温度応力による応力の方が大きく, 側部コン クリートピットでは圧縮方向に，側部低拡散層 では引張方向に作用する。ただし，側部低拡散

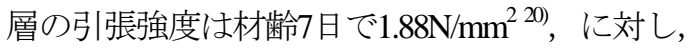




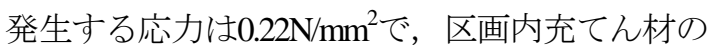
施工が，側部低拡散層のひび割れの主要な因子 とはならないものと考える。

本施工確認試験により，区画内充てん材の施工性の確 認と施工に伴う施設の品質の確認ができたと考えられる. これらの結果は，低レベル放射性廃棄物の発電所から発 生する低レベル放射性廃棄物の余裕深度処分をはじめ, TRU廃棄物の余裕深度処分の共通的基盤技術として幅広 く反映できるものである.

謝辞 : 本報告は経済産業省の委託により実施した管理型 処分技術調査等事業「地下空洞型処分施設性能確証試 験」の結果の一部をとりまとめたものである（平成20〜 22年度）。試験の計画および試験結果の評価にあたつて は，専門家からなる「地下空洞型処分施設性能確証試験 検討委員会」を設け，関連する知見や意見等を幅広く取 り入れた. 関係各位に感謝の意を表する.

\section{参考文献}

1) 坪谷隆夫, 寺田賢二, 松村勝秀, 大沼和弘, 窪田 茂：地下空洞型処分施設性能確証試験一計画概要一, 土木学会第 62 回年次講演会, CS5-073, pp.305-306, 2007.

2) 土木学会 : 余裕深度処分の地下施設の設計, 品質管 理および検査の考え方， 2009.

3) 高柳達徳, 横関康祐, 新保弘, 武地真一, 根木政広, 杉橋直行, 秋山吉弘, 矢田勤, 山田淳夫 : 低発熱型 セメントを用いたコンクリートおよびモルタルの長 期材齢における諸性状，土木学会第 68 回年次講演会, CS11-031, pp.61-62, 2013.

4) 日本建築学会 : 建築工事標準仕様書 - 同解説 JASS5N 原子力発電所施設における鉄筋コンクリート工事, pp.161-162, 2001.

5) 新保弘, 戸梶慎一, 武地真一，木ノ村幸士，根木政広， 杉橋直之，秋山吉弘 : 発熱廃棄体の表面温度に関する検 討一地下空洞型処分施設性能確証試験一，土木学会第 65 回年次講演会, CS7-004, pp.7-8, 2010.

6) 千田太詩, 杉山大輔 : フライアッシュ混合セメント 硬化体中における有機炭素およびヨウ素の拡散挙動, 電力中央研究所報告, 2008 .

7) 庭瀬一仁，杉橋直行，辻幸和：低レベル放射性廃棄 物施設の低拡散層に用いる高流動モルタルの室内配
合選定，コンクリート工学論文集，Vol.21，No.3， pp.43-51, 2010.

8) 土木学会 : 2012 年制定コンクリート標準示方書【施工 編】, pp.232, 2012.

9) 坂部大, 名和豊春, 大久保正弘：高ビーライト系セ メントを用いたモルタルの蒸気養生における強度発 現性，コンクリート工学論文集，Vol.17，No.1， pp.469-474, 1995.

10) 高田誠, 岡沢智, 松尾茂美, 阿合延明：超遅延性減 水剂の凝結遅延機構と性能評価, エヌエムビー研究 所報, No.9, pp.57-67, 1992.

11) Portland Cement Association: Design and Control of Concrete Mixtures, 14 $4^{\text {th }}$ edition, pp.226, 2002.

12）庭瀬一仁, 杉橋直行, 辻幸和：低レベル放射性廃棄 物施設の実規模試験による初期性能の設定，コンク リート工学論文集, Vol.21, No.3, pp.53-62, 2010.

13) 鈴木一孝, 西川直宏 : コンクリートの耐久性評価を 目的とした水和組成の分析手法に関する研究，コン クリート工学論文集，Vol.34，pp.39-49，1990.

14) 小早川真, 黄光律, 羽原俊祐, 友澤史紀 : 水比, 混 合率および養生温度がフライアッシュのポゾラン反 応に及ぼす影響, コンクリート工学年次論文報告書, Vol.21, No.2, pp.121-126, 1999.

15) 土木学会 : コンクリートのポンプ施工指針, pp.4, 2000.

16) 小平伸彦, 熊野知司, 大西隆雄, 西岡真帆: 高流動 コンクリートのポンプ圧送による品質変化に関する 現場計測, コンクリート工学年次論文集, Vol.28, No.1, pp.1157-1162, 2006.

17）田中俊行，小林裕，福田勝美，広中良和，村上利一，枝 松良展，川崎康司 : 余裕深度処分におけるセメント系人 工バリアの現場施工に関する検討（その 3）－高流動モル タル打設時の側圧に関寸る考察一, 土木学会第 62 回年次 講演会, CS05-035, pp.229-230, 2007.

18）新保弘, 金澤亮一, 福田勝美, 窪田茂, 杉橋直行, 根木 政広，寺田賢二 : 地下空洞型処分施設性能確証試験にお けるコンクリートピット等施工確認試験に関する検討, 土木学会第 64 回年次講演会, CS5-022, pp.177-178, 2009.

19) 土木学会 : 2012 年制定コンクリート標準示方書【施工 編】 , pp.236, 2012.

20) (公財)原子力環境整備促進・資金管理センター：平成 21 年度管理型処分技術調查等地下空洞型処分施設性 能確証試験報告書, 2010 .

(2012.12.11受付) 


\title{
EVALUATION ON CONSTRUCTION QUALITY OF PIT FILLER MATERIAL OF CAVERN TYPE RADIOACTIVE WASTE DISPOSAL FACILITY
}

\author{
Shin-ichi TAKECHI, Kosuke YOKOZEKI, Hiroshi SHIMBO, \\ Kenji TERADA, Yoshihiro AKIYAMA, Tsutomu YADA and Yukikazu TSUJI
}

The pit filler material of the underground cavern-type radioactive waste disposal facility, which is poured directly around the radioactive waste packages where high temperature environment is assumed by their decay heat, is concerned to be adversely affected on the filling behavior and its hardened properties. There also are specific issues that required quality of construction must be achieved by unmanned construction with remote operation, because the pit filler construction shall be done under radiation environment.

In this paper, the mix proportion of filler material is deliberated with filling experiments simulating high temperature environment, and also the effect of temperature on hardened properties are confirmed with high temperature curing test. Subsequently, the feasibility of unmanned construction method of filler material by pumping, and by movable bucket, are comparatively discussed through a real size demonstration. 